


\title{
Status of the Slender Mouse-ear-cress (Halimolobos virgata) in Alberta
}

\author{
Prepared for: \\ Alberta Sustainable Resource Development (SRD) \\ Alberta Conservation Association (ACA)
}

Prepared by:

Ian D. Macdonald

This report has been reviewed, revised, and edited prior to publication. It is an SRD/ACA working document that will be revised and updated periodically.

Alberta Wildlife Status Report No. 55

January 2005

Published By:

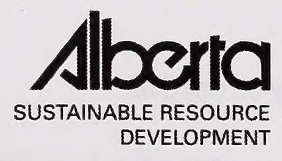

Fish \& Wildlife

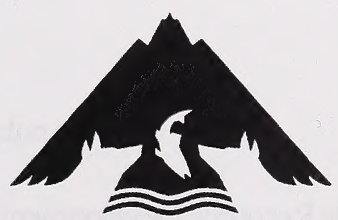

Alberta Conservation Association 
Publication No. T/066

ISBN: 0-7785-3652-1 (Printed Edition)

ISBN: 0-7785-3653-X (On-line Edition)

ISSN: 1206-4912 (Printed Edition)

ISSN: 1499-4682 (On-line Edition)

Series Editors: Sue Peters, Nyree Sharp and Robin Gutsell

Illustrations: Brian Huffman

Maps: Jane Bailey

For copies of this report,visit our web site at :

http://www3.gov.ab.ca/srd/fw/riskspecies/

and click on "Detailed Status"

$O R$

Contact:

Information Centre - Publications

Alberta Environment/Alberta Sustainable Resource Development

Fish and Wildlife Division

Main Floor, Great West Life Building

9920 - 108 Street

Edmonton, Alberta, Canada T5K 2M4

Telephone: (780) 422-2079

This publication may be cited as:

Alberta Sustainable Resource Development. 2005. Status of the slender mouse-ear-cress (Halimolobos virgata) in Alberta. Alberta Sustainable Resource Development, Fish and Wildlife Division, and Alberta Conservation Association, Wildlife Status Report No. 55, Edmonton, AB. 27 pp. 


\section{PREFACE}

Every five years, the Fish and Wildlife Division of Alberta Sustainable Resource Development reviews the general status of wildlife species in Alberta. These overviews, which have been conducted in 1991 (The Status of Alberta Wildlife), 1996 (The Status of Alberta Wildlife) and 2000 (The General Status of Alberta Wild Species 2000), assign individual species "ranks" that reflect the perceived level of risk to populations that occur in the province. Such designations are determined from extensive consultations with professional and amateur biologists, and from a variety of readily available sources of population data. A key objective of these reviews is to identify species that may be considered for more detailed status determinations.

The Alberta Wildlife Status Report Series is an extension of the general status exercise, and provides comprehensive current summaries of the biological status of selected wildlife species in Alberta. Priority is given to species that are At Risk or May Be At Risk in the province, that are of uncertain status (Undetermined), or that are considered to be at risk at a national level by the Committee on the Status of Endangered Wildlife in Canada (COSEWIC).

Reports in this series are published and distributed by the Alberta Conservation Association and the Fish and Wildlife Division of Alberta Sustainable Resource Development. They are intended to provide detailed and up-to-date information that will be useful to resource professionals for managing populations of species and their habitats in the province. The reports are also designed to provide current information that will assist Alberta's Endangered Species Conservation Committee in identifying species that may be formally designated as Endangered or Threatened under Alberta's Wildlife Act. To achieve these goals, the reports have been authored and/or reviewed by individuals with unique local expertise in the biology and management of each species. 


\section{EXECUTIVE SUMMARY}

Slender mouse-ear-cress (Halimolobos virgata [Nutt.] O.E. Schulz), is a member of the mustard family (Brassicaceae), and is the only species of the genus Halimolobos that occurs in Alberta. It has a very limited known recent range in the Dry Mixedgrass Natural Subregion of the Grassland Natural Region in the southeastern portion of Alberta. It is known from only 17 sites in nine separate general locations, with historical locations at Medicine Hat and possibly Rosedale near Drumheller, and recent locations between Duchess and McNeill. The populations have been recorded only sporadically, with records of live plants in Alberta from 1894, 1914 (unconfirmed), 1978, 1995, 1996, 1997, 1999 and 2004, and a population estimate of between 500 and 1000 plants in 1997, and 1575 in 2004. The total known area for this species is just over $3000 \mathrm{~m}^{2}$ and the total potential habitat in Alberta is between $297 \mathrm{~km}^{2}$ and $10000 \mathrm{~km}^{2}$.

Slender mouse-ear-cress is considered May Be At Risk in Alberta, according to the general status exercise conducted in 2000 by Alberta Sustainable Resource Development (Alberta Sustainable Resource Development 2000), and is ranked as S1 (Vujnovic and Gould 2002, Alberta Natural Heritage Information Centre 2003). It is listed as Threatened in Canada (COSEWIC 2003), and is on Schedule 1 of the federal Species at Risk Act (Government of Canada 2003). Outside Alberta, it occurs only in southwestern Saskatchewan, with only nine reported locations. It occurs in six western states, and is considered rare in Colorado, Utah and California.

The ecological requirements of slender mouse-ear-cress in the province are not well understood. It appears to be able to withstand, and perhaps even require, light disturbance from grazing, but it probably cannot tolerate intense competition from more aggressive plant species. As with many of the rare species in Alberta, loss of habitat probably ranks as the greatest long-term threat to this species. 


\section{ACKNOWLEDGEMENTS}

Bonnie M. Smith (Herbarium Technician, Vascular Plant Herbarium, Department of Biological Sciences, University of Calgary, Calgary) for her generosity in sharing her experience with the species in Alberta, without which this report would not be possible; Candace Elchuk (Biologist, Canadian Wildlife Service, Saskatoon, SK) for sharing information on her relocations in the province from 2004, and for her fresh insight into the habitats of the species; Susan Peters (Biologist, Alberta Conservation Association, Edmonton) for her encouragement in the field survey and research phases of this project and her excellent, thorough and insightful review of this report; Andy Didiuk (Biologist, Canadian Wildlife Service, Species at Risk Division, Environment Canada, Saskatoon, SK) and Robin Gutsell (Provincial Resource Assessment Biologist, Alberta Sustainable Resource Development, Fish and Wildlife Division, Edmonton) for their support of the 2002 and 2003 field survey and research phases of this report; Nyree Sharp (Biologist, Alberta Conservation Association, Edmonton) for her review of the final stages of this report; Ksenija Vujnovic, (Botanist, Alberta Natural Heritage Information Centre, Parks and Protected Areas Division, Edmonton) for providing information on the known sites in Alberta; John Rintoul (Data Manager, Alberta Natural Heritage Information Centre, Edmonton) for information on the reported Rosedale and Cypress Hills sites and conservation issues in Alberta; Sheila Lamont (Botanist), Jeff Keith (Data Manager) and Ann Gerry (Senior Biodiversity Specialist) (all from the Saskatchewan Conservation Data Centre, Regina, SK) for information on the recent efforts to locate the species in Saskatchewan and clarification of the Cypress Hills sites; Mike Shchepanek, (Collections Manager, Vascular Plant Herbarium, The Canadian Museum of Nature, Ottawa, ON) for locating H.J. Scoggan's original data file record of M.E. Moodie's 1914 collection from the Rosedale location, and to Dr. Marcia Waterway (Curator, Vascular Plant Herbarium, McGill University, Montreal, QC), Dr. Paul M. Catling (Curator, National Herbarium, Agriculture and Agri-food Canada, Ottawa, ON) and Christine Niezgoda (Collections Manager, Vascular Plant Herbarium, Field Museum, Chicago, IL) for their searches for the actual Rosedale specimen; Bonnie Heidel (Botanist, Wyoming Natural Diversity Data Center, Laramie, WY) for sharing her information on the species' habitats and distribution in Wyoming and Montana, and for providing the invaluable correspondence with Walter Fertig (Botanist/Vegetation Team Leader, Grand Staircase-Escalante National Monument, Kanab, UT) on his knowledge of the locations and habitats for the species in Wyoming and Montana; Dr. C.C. Chinnappa (Curator, Vascular Plant Herbarium, Department of Biological Sciences, University of Calgary, Calgary) for allowing access to the herbarium collections; Bob Hale (Grazing Lease Manager, Duchess Community Pasture Association, Duchess) and Fred Wittig (Landowner, Burstall, SK) for providing grazing management information on the locations under their management in Alberta; Jane Lancaster (Kestrel Consulting, Cochrane) for sharing her information on the species in Alberta; Garry C. Trottier (Biologist, Canadian Wildlife Service, Environment Canada, Edmonton) for updated information on the species' location in Canadian Forces Base Suffield National Wildlife Area; Dr. Geoffrey L. Holroyd (Biologist, Canadian Wildlife Service, Environment Canada, Edmonton) for information on remaining native prairie in western Canada; and Hugh D.J. McLean (Agrometeorology Research Technician, Agriculture and Agri-Food Canada, Lethbridge, $\mathrm{AB}$ ) for information on prairie climate and drought conditions.

Preparation of this report was funded by the Alberta Conservation Association and the Fish and Wildlife Division of Alberta Sustainable Resource Development. 
Digitized by the Internet Archive in 2016 


\section{TABLE OF CONTENTS}

PREFACE

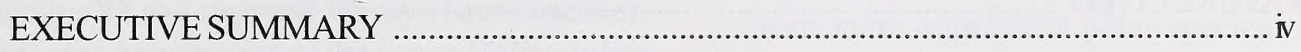

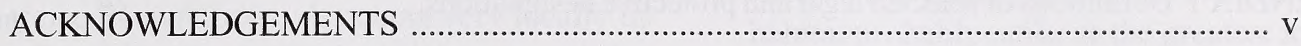

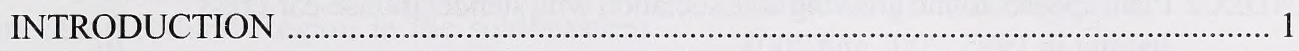

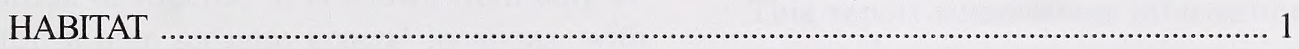

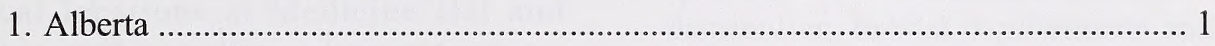

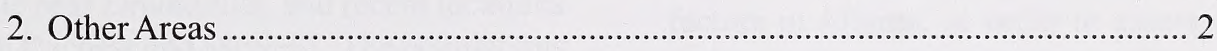

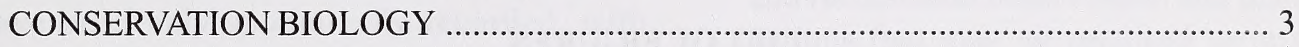

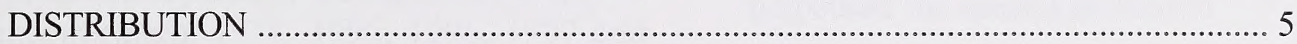

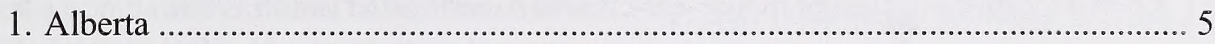

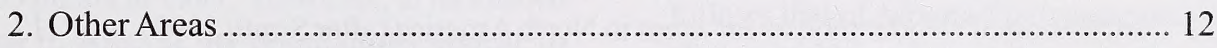

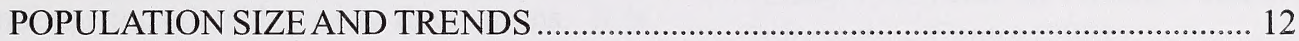

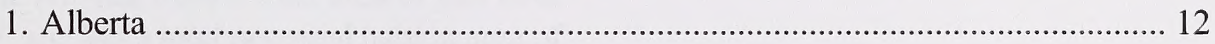

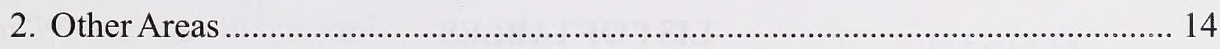

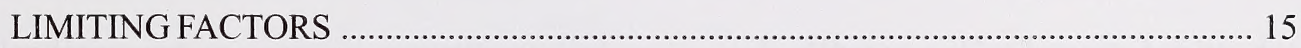

1. Habitat Loss, Alteration and Fragmentation …………....................................... 15

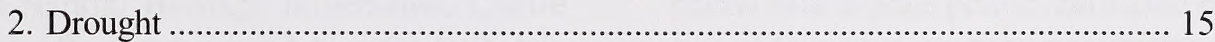

3. Reduction/Absence of Grazing Disturbance ………........................................... 15

4. Competition from Introduced Species ............................................................ 16

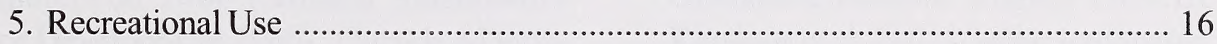

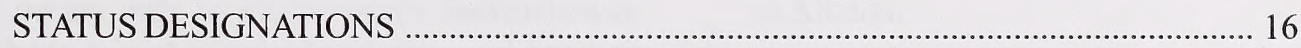

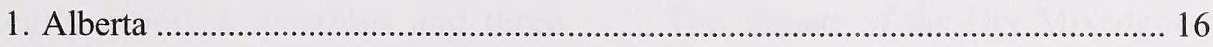

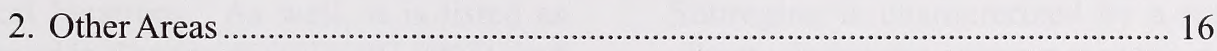

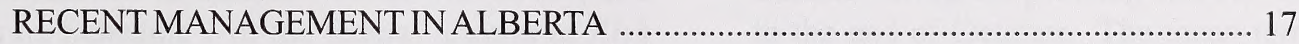


APPENDIX 1 Definitions of selected legal and protective designations.

APPENDIX 2 Plant species found growing in association with slender mouse-ear-cress habitat in 1995, 2002 and 2003

\section{LIST OF FIGURES}

Figure 1 Known locations of slender mouse-ear-cress in Alberta (after Smith 1999) 6

Figure 2 Distribution of slender mouse-ear-cress in North America (after Smith 1999) 13

\section{LIST OF TABLES}

Table 1 Descriptions of all known slender mouse-ear-cress locations in Alberta, and the size of known and potential habitats at each location

Table 2 The number of slender mouse-ear-cress plants (stems) at known locations in Alberta, for each survey year 


\section{INTRODUCTION}

Slender mouse-ear-cress, also called virgate halimolobos and lesser mouse-ear-cress, (Halimolobos virgata [Nutt.] O.E. Schulz), is a member of the mustard family (Brassicaceae), and is the only species of the genus Halimolobos that occurs in Alberta. It occurs very locally in the Dry Mixedgrass Natural Subregion of the Grassland Natural Region in the southeastern portion of Alberta. It is known from only 17 sites in nine separate general locations, with historical locations at Medicine Hat and Rosedale near Drumheller, and recent locations between Duchess and McNeill. The populations have been only sporadically recorded, with records of live plants in Alberta from 1894, 1914 (unconfirmed), 1978, 1995, 1996, 1997 and 1999, and a population estimate of between 500 and 1000 plants in 1997 . However, at its known locations in Alberta, its populations appear to undergo considerable yearly fluctuations. It is known in Alberta from a total area of just over $3000 \mathrm{~m}^{2}$, and has a total potential habitat area of between $297 \mathrm{~km}^{2}$ and $10000 \mathrm{~km}^{2}$.

Slender mouse-ear-cress is currently ranked as S1 in the province (Vujnovic and Gould 2002, Alberta Natural Heritage Information Centre 2003). It also is considered May Be At Risk in Alberta, according to the general status exercise conducted by Alberta Sustainable Resource Development in 2000 (Alberta Sustainable Resource Development 2000). Outside Alberta, it occurs only in southwestern Saskatchewan, where it is also considered rare, and has only six recently reported locations and three historical locations. As well, it is listed as Threatened in Canada (COSEWIC 2003), and is on Schedule 1 of the federal Species at Risk Act (Government of Canada 2003). In the United States, slender mouse-ear-cress is rare (S1 or S2) in three of the seven western states in which it occurs: Utah, Colorado and California (NatureServe 2004).

* See Appendix 1 for definitions of selected status designations.
The ecological requirements of slender mouseear-cress are not well understood in the province. It appears to be able to withstand, and perhaps even require, light disturbance from grazing, but it probably cannot tolerate intense competition from more aggressive plant species. As with many of the rare species in Alberta, loss of habitat probably ranks as the greatest long-term threat to this species.

This report summarizes information on the species' known recent and historical locations, distribution, habitat requirements and limiting factors in Alberta, in order to assess its status and recommend conservation and management actions that may be required to protect and perpetuate the species in Alberta.

Use of scientific and common names in the text follows that of Alberta Environmental Protection (Ealey 1993) and the Alberta Natural Heritage Information Centre (2001).

\section{HABITAT}

1. Alberta - The known habitat for slender mouse-ear-cress is restricted to lightly disturbed prairie of mid-grass prairie and mixed grasslands on sand plains and open sage thickets of river slopes and basins. This habitat is found in the Dry Mixedgrass Natural Subregion of the Grassland Natural Region (ANHIC 2002a, Kershaw et al. 2001), in the southeastern portion of Alberta.

The climate of the Dry Mixedgrass Natural Subregion is characterized by a warm, dry climate during the growing season: early May to the end of October. The mean temperature during this time is $16.2^{\circ} \mathrm{C}$, and maximum temperatures typically range between $30^{\circ} \mathrm{C}$ and $35^{\circ} \mathrm{C}$, with July and August being the hottest months (Usher and Strong 1994). The mean summer precipitation of $150 \mathrm{~mm}$ is among the lowest observed in any of the natural subregions in Alberta. Most of the precipitation falls between May and late July. The drought 
conditions from 2000 through early 2002 had notably reduced the precipitation in the known provincial range of slender mouse-ear-cress, with the overall effect being that the driest southern portion of the Palliser Triangle, which normally extends in eastern Alberta between the Canadian border and Medicine Hat, had shifted northward (H.D.J. McLean, pers. comm.). In 2002 , the summer precipitation across the known range of slender mouse-ear-cress in Alberta was only $40 \%$ to $60 \%$ of its normal $100 \mathrm{~mm}$ to 200 mm (Alberta Environment 2003), and in 2003 only between $40 \%$ and $80 \%$ of the normal rainfall was achieved (Agriculture and AgriFood Canada 2003). In 2004, however, the region received its normal rainfall (H.D.J. McLean, pers. comm.).

Most of the known locations for slender mouseear-cress occur on gently rolling prairies. The prairie locations have landforms and substrate materials that include undulating glaciofluvial (glacial river-deposited) sands and sandy loams with overlying aeolian (wind-deposited) sands and low dunes or significant inclusions of aeolian and lacustrine (lake-deposited) sand or sandy loams, and hummocky to undulating moraines with till and fluvial sandy loams and sands. The soils in these general locations include the sands and sandy loams of orthic chernozemic, orthic brown chernozemic, orthic regosol, rego chernozemic and rego brown chernozemic soil types in eight soil series (Alberta Soil Survey, no date). The habitat conditions of the plants are a subxeric (moderately dry) to occasionally xeric (very dry) moisture regime situated on flat to very gently undulating sand plain, often associated with low sand dune edges, although not actually on the dune slopes, or in dry to vernally (during the spring) moist low depressions with level to usually less than $5 \%$ slope at variable aspects. The associated vegetation includes June grass (Koeleria macrantha), needle-and-thread grass (Stipa comata), western porcupine grass (Stipa curtiseta), slender wheat grass (Agropyron [= Elymus] trachycaulum), western wheat grass (Agropyron [= Pascopyrum $]$ smithii), low sedge
(Carex stenophylla), goosefoot (Chenopodium pratericola), reflexed rock cress (Arabis holboellii var. retrofracta) and whitlow-grass (Draba reptans), or a low shrubby prairie or thicket cover of silver sagebrush (Artemisia cana) and prickly pear (Opuntia polyacantha). In marginal sites, the species occurred with common wild rose (Rosa woodsii), buckbrush (Symphoricarpos occidentalis) and, occasionally, silverberry (Elaeagnus commutata) that may have provided wind shelter or moisture sinks (Smith 1999, Macdonald 1997).

Three valley locations for the species in the valleys of the South Saskatchewan and Red Deer rivers have dissected and steeply inclined undifferentiated (very mixed) materials or recent alluvial (river-deposited) sand and gravels, with rough broken, cumulic regosol and recent sand and gravel alluvium soils (Alberta Soil Survey, no date). The reported habitats of slender mouseear-cress here have a submesic (moderately moist) moisture regime with a $3 \%$ to $8 \%$ slope at a southerly aspect. The species occurred in association with shrubby sage grassland where there was at least light grazing disturbance. The two historical river valley locations have little or no habitat information, and the single recent location was reported to have had a shrubby grassland of silver sagebrush, with a herb cover of reflexed rock cress, prairie onion (Allium textile) and western bluebur (Lappula occidentalis) in the late 1970s (Smith 1991); however, the area has since become infested with a dense herb cover consisting exclusively of crested wheat grass (Agropyron pectiniforme) (Macdonald 2002). See Appendix 2 for a complete list of species with which slender mouse-ear-cress has been found in Alberta.

2. Other Areas - In Saskatchewan, the variety of habitats for slender mouse-ear-cress includes plains and ravines in the Mixed Grassland Ecoregion (Saskatchewan Conservation Data Centre 2003). Between the Alberta border and Diefenbaker Lake, the species occurs on the upland plain subxeric short-grass and mixedgrass prairies on slightly disturbed grassy flats 
or overgrazed prairie with a high association of ephemeral annuals including annual whitlowgrass (Draba nemorosa), western bluebur and reflexed rock cress. In ravines and benches, it occurs with very slight cover of June grass, Sandberg bluegrass (Poa sandbergii), western bluebur, narrow-leaved goosefoot (Chenopodium leptophyllum) and narrow-leaved milk-vetch (Astragalus pectinatus). On the south-facing slopes of ravine sites, it was found on clay in overgrazed prairie with low sedge, prairie selaginella (Selaginella densa) and early bluegrass (Poa cusickii); at one xeric southfacing slope base it was found with prairie onion, western fairy candelabra (Androsace occidentalis) and annual whitlow-grass; and at a reservoir shore site it occurred in mixed grass prairie with reflexed rock cress (Smith 1991). At the historical sites from the mid-1890s in the Cypress Upland Ecoregion at the Cypress Hills and Wood Mountain areas, it was recorded only from "meadows" (Smith 1991).

Although the species has been recorded from only plains habitats in Alberta, toward the southern portion of its range in the United States its diversity of habitats expands to include river backshores, granitic gravel deposits and woodlands. In the adjacent state of Montana, the species generally occurs in dry grassland regions in the prairies, and in foothill and lower montane areas of its Rocky Mountain sites (Booth and Wright 1959). It is notable that the species occurs in an open grassland habitat on the north-facing lower slopes of the Sweetgrass Hills' East Butte, which is within $10 \mathrm{~km}$ of the Alberta border (B. Heidel, pers. comm.). In Wyoming, W. Fertig reported slender mouse-earcress from a wider variety of habitats in montane and prairie habitats, especially in rocky limestone outcrops or calcareous soils in sagebrush communities, as well as on grassy rocklands with granitic, sandstone and shale substrates, clay and alkaline flats, and ravines (Dorn 1977, B. Heidel, pers. comm.). Similarly, it has been reported in Utah between elevations $2100 \mathrm{~m}$ and $2700 \mathrm{~m}$ in granitic alluvial gravels, creek bottoms, moist meadows on clay loam soils, and even a "sheep bedding ground" on a windswept ridge (New York Botanical Garden 2002, Welsh et al. 1987). Along the southwestern limits of its range in California, it is reported from "meadows, near aspen groves, pinyon/juniper woodland [at] $2000 \mathrm{~m}$ to 3000 m" (Hickman 1993).

\section{CONSERVATION BIOLOGY}

Slender mouse-ear-cress is a biennial herb (possibly flowering in the first year) that is characterized by the following technical features (see footnote* for definitions of botanical terms): tap root; basal leaf rosette is of oblanceolate, denticulate to dentate, 2-6 cm-long and 3-20 mm-wide leaves; stem is erect and $25-50 \mathrm{~cm}$ tall; cauline leaves are auriculate or sessile and become reduced upwards; inflorescence is of single or a series of open racemes; pedicels are 6-12 $\mathrm{mm}$ long and extend from the stem at a $45^{\circ}$ angle; petals are white and pinkish-veined, erect and small $(3-4.5 \mathrm{~mm}$ long); fruits are distinctive glabrous, subquadrangular to terete siliques, $15-40 \mathrm{~mm}$ long and $1-1.5 \mathrm{~mm}$ wide, with irregularly biseriate, wingless seeds, and a persistent 0.2-0.5 mm-long style (Moss 1983, Douglas et al. 1998b, Scoggan 1978, Hitchcock et al. 1964).

\footnotetext{
*Definitions of botanical terms used in this section: Oblanceolate $=$ spoon-shaped; denticulate $=$ toothed; dentate $=$ with teeth pointed outward; cauline $=$ along the stem; auriculate $=$ with ear-like lobes at the base; sessile $=$ without a stalk; inflorescence $=$ flowering head; raceme $=$ narrow, wand-like flowering head; pedicel $=$ the stalk of a single flower in a cluster; glabrous = hairless; subquadrangular $=$ almost square-shaped in cross section; terete $=$ circular in cross-section; silique $=$ pod-like fruit that has its sides attached to a central wall; biseriate $=$ in two rows; style $=$ the structure connecting the ovary/fruit and the pollen receptacle.
} 
The species appears to be closely related to several other members of the mustard family, notably in the genera Arabis, Sisymbrium and Hesperis, and it has had a variety of synonyms, including Sisymbrium virgatum Nutt ex Torrey and Gray, Pilosella virgata (Nutt.) Rydb., Pilosella stenocarpa (Rydb.) Rydb., Stenophragma virgatum (Nutt.) Greene, Arabidopsis virgata (Nutt.) Rydb., Arabis brebneriana A. Nels., and others (Scoggan 1978, Welsh et al. 1987, Dorn 1977, Kershaw et al. 2001, Kartesz 1994a, 1994b). It is the only species of the genus Halimolobos that occurs in Alberta. There are two other species of Halimolobos in Canada: soft mouse-ear-cress (H. mollis [Hook.] Rollins), which has been reported from Nunavut, Northwest Territories, Yukon and Alaska, and Whited's halimolobos (H. whitedii [Piper] Rollins), a species that occurs in British Columbia, where it is considered rare (Douglas et al. 1998a, 1998b).

The following critical diagnostic characteristics will distinguish slender mouse-ear-cress from the several similar species with which it most commonly may be confused in Alberta: 1) distinctive hairs on the basal and lower cauline leaves and lower stem that include a semi-open, velvety cover of very short, thrice-branching, dendritic (branched or splitting) hairs, over which is an open cover of taller, linear and often somewhat flattened hairs (Sisymbrium altissimum seedlings have simple hairs and Arabis holboellii var. retrofracta has only the stellate hairs); and 2) flowering and fruiting pedicels extend from the stem at a notable $45^{\circ}$ angle (Erysimum inconspicuum has very similar fruits, but they are less angled, and it has yellow flowers, the several prairie Arabis species have either more acutely ascending fruits or distinctly reflexed, drooping fruits, and the several prairie species of Descurania have arching fruits, yellow flowers and deeply cleft pinnate leaves).

Several of the above physical characters are important features to the conservation biology of this species. The plants generally are biennial, with a tap root and basal rosette of leaves produced the first year, and flower and seed production occurring in the second year following germination. However, the species has been reported to be able to produce flowers and seeds in the first season, and the plant may be able to survive more than two seasons. These foreshortened and prolonged life histories have been documented in the American populations, perhaps where the seasons are longer and have suitable precipitation regimes for such early flowering in the first case, and where the winter conditions allow sufficient protection for the root and stem to persist in the second (Dorn 1977, Welsh et al. 1987, Hickman 1993). This conceivably could allow multiple generations of seed production from single plants; however, no documentation for such a potentially productive situation for the populations could be found in the cited studies. The assumed situation for the species in Alberta is that, given the exposed habitats that afford little protection from the summer and winter environments, the species is at least a biennial, with seed production occurring in the second year.

The flowers are produced from May to June in Alberta, and possibly somewhat earlier (midApril) and later (mid-July) in American populations (Dorn 1977, Welsh et al. 1987, Hitchcock et al. 1964, Kershaw et al. 2001). There is no information on available, suitable pollinating insects in the vicinity of the known slender mouse-ear-cress populations in Alberta. An examination of the 1996 specimens from the McNeill location at the University of Calgary Herbarium revealed that each productive plant had one to three, and occasionally up to eight, elongated inflorescences, each of which could produce 15 to 25 ( 12 to 30 ) individual flowers. If successfully pollinated, such inflorescences could produce at least 10 to 25 siliques (fruits), although the several Alberta specimens examined appeared to produce only 4 to 15 fruits. Each of the fruits can enclose approximately 20 (16 to 26) seeds. Additionally, an examination of the species' reproductive potential at the 
McNeill location in 2004 indicated that about 40 seeds per silicle, 20 silicles per stem and 23 stems per plant was typical (C. Elchuk, pers. comm.). Hence, assuming the plants can survive early-and mid-summer desiccation, the average plant should be able to produce between 100 and 400 seeds before mid-July. The fruits mature and dehisce (split) before mid-July, and apparently shed their seeds readily. The seeds are held to the dry silique only by a thin stalk, and they readily pull away from the septum. The prairie winds undoubtedly shake the stalks and further aid in the shedding of the seeds, but since the seeds have only narrow wings, they are not adapted to being blown long distances by the winds.

There is no information on the rates of seed germination or of the survival of seedlings. Viable seeds probably can survive summer conditions until cooler and moister weather may allow them to germinate later in the summer and in the following spring; however, there is no information on actual seedling survivability over the winter or as summer dry periods advance. During the early summer surveys of 1999 and 2002, no recognizable seedlings were recorded in the vicinities of the known locations in the province-this may be attributed to the prolonged drought conditions of the previous year, when no fruits or seedlings were produced, or to the seedlings' desiccation as they germinated in the early spring (B.M. Smith, pers. comm.; Macdonald 2002).

Where the species has been located in Alberta and elsewhere, it is evident that some degree of light disturbance influences the habitat. Most of the locations in Alberta have had light grazing, and management of the range pasturage for cattle has maintained a normal light rotation of intensity and duration (F. Wittig, pers. comm.; B. Hale, pers. comm.). This species is not favoured by cattle, although incidental browsing and associated trampling may be expected to occur. Indeed, a modest level of physical disturbance to the ground that exposes sand and creates depressions may assist in seedling establishment, and it is interesting to note that one habitat in Utah was a "sheep bedding ground" (New York Botanical Garden 2002).

Several observers (Smith 1999; B.M. Smith, pers. comm.; B. Heidel, pers. comm.) have reported that, whereas the plants are associated with grassland-dominated communities, they tend to be positioned in close proximity to the shrubs of silver sagebrush, or stout succulents, such as prickly pear. They suggest that these larger plants may provide a degree of cover and protection for the seedlings and mature plants. They also suggest that winter snow deposits in the lee of mounds and around depressions may afford some protection to seedlings and plants, and that these conditions may also provide needed ground moisture in the late autumn or early growing season.

\section{DISTRIBUTION}

1. Alberta - The known distribution in Alberta for slender mouse-ear-cress is restricted to the southeastern portion of the province, in an area roughly bounded by Medicine Hat, Empress (close to the Saskatchewan border) and Duchess (Figure 1). John Macoun first collected this species in Alberta in 1894 at Police Point Park in Medicine Hat (Table 1; location 7). A second collection record from the Cypress Hills by J. Macoun a year later, reported in Smith (1991, 1999), recently has been determined by J.H. Soper (former curator of the National Herbarium in Ottawa) to be likely from Saskatchewan instead of Alberta, on the southern side of the hills (M. Shchepanek, pers. comm.; J. Rintoul, pers. comm.; J. Keith, pers. comm.). A voucher collection by M.E. Moodie in 1914 from a location at Rosedale (near Drumheller; location 9) that was reported in Scoggan (1978), but omitted by Smith $(1991,1999)$, was sought at several promising herbaria (Canadian Museum of Nature, Ottawa; National Herbarium, Ottawa; McGill University, Montreal; Field Museum, Chicago), but was not found (M. Shchepanek, 


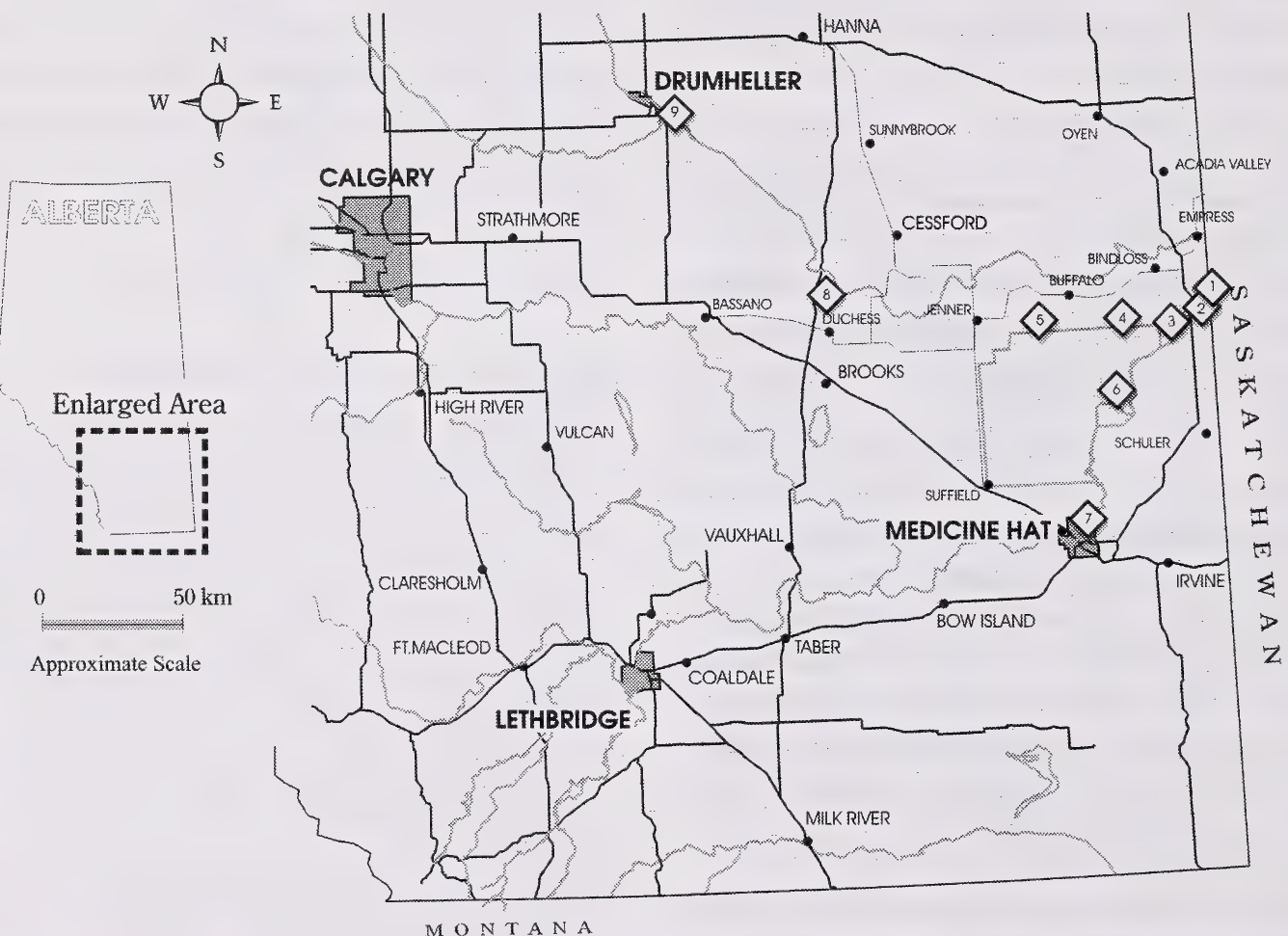

Figure 1. Known locations of slender mouse-ear-cress in Alberta (after Smith 1999). Numbers correspond to locations listed in Tables 1 and 2. Location 9 is unconfirmed. 


\begin{tabular}{|c|c|c|c|c|c|c|c|}
\hline & 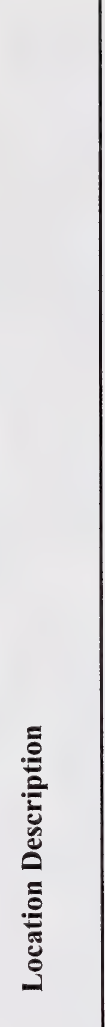 & 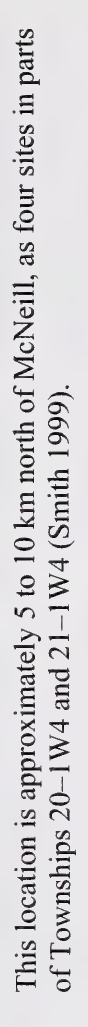 & 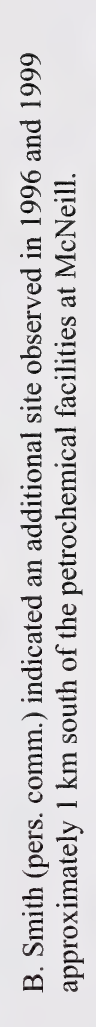 & 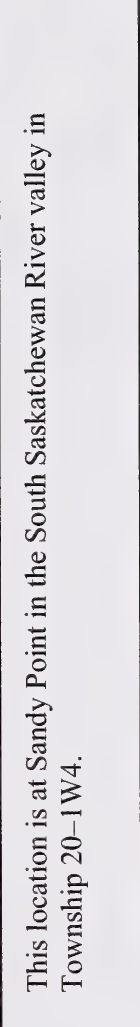 & 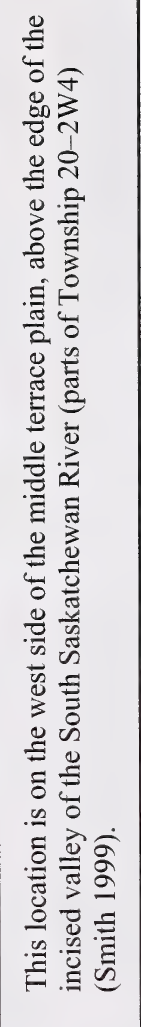 & 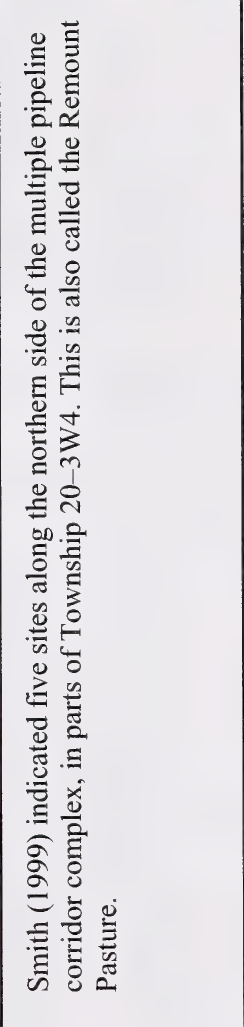 & 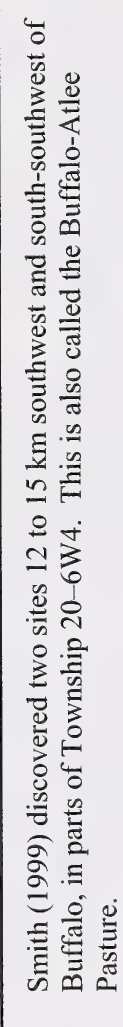 \\
\hline & 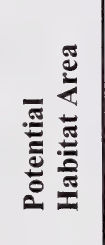 & $\frac{d}{4}$ & 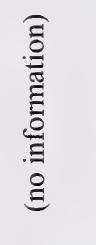 & $\underline{\underline{E}}$ & $\frac{5}{6}$ & 踣 & 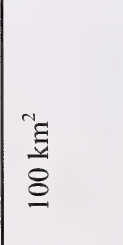 \\
\hline & 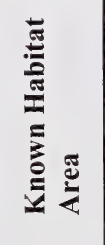 & 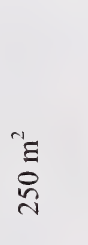 & 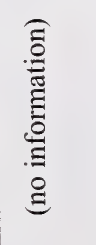 & 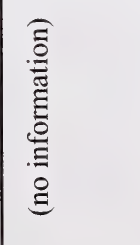 & $\stackrel{E}{\varrho}$ & 吾 & 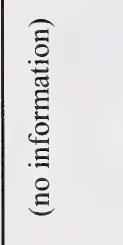 \\
\hline & 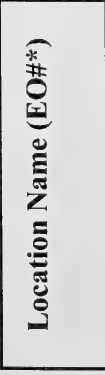 & 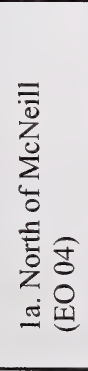 & 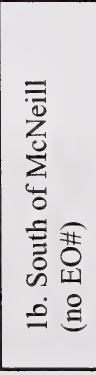 & 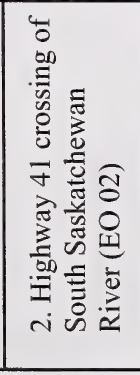 & 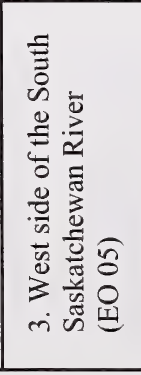 & 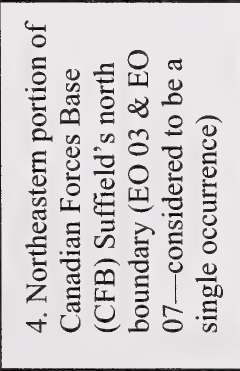 & 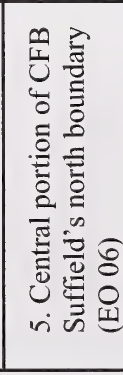 \\
\hline
\end{tabular}




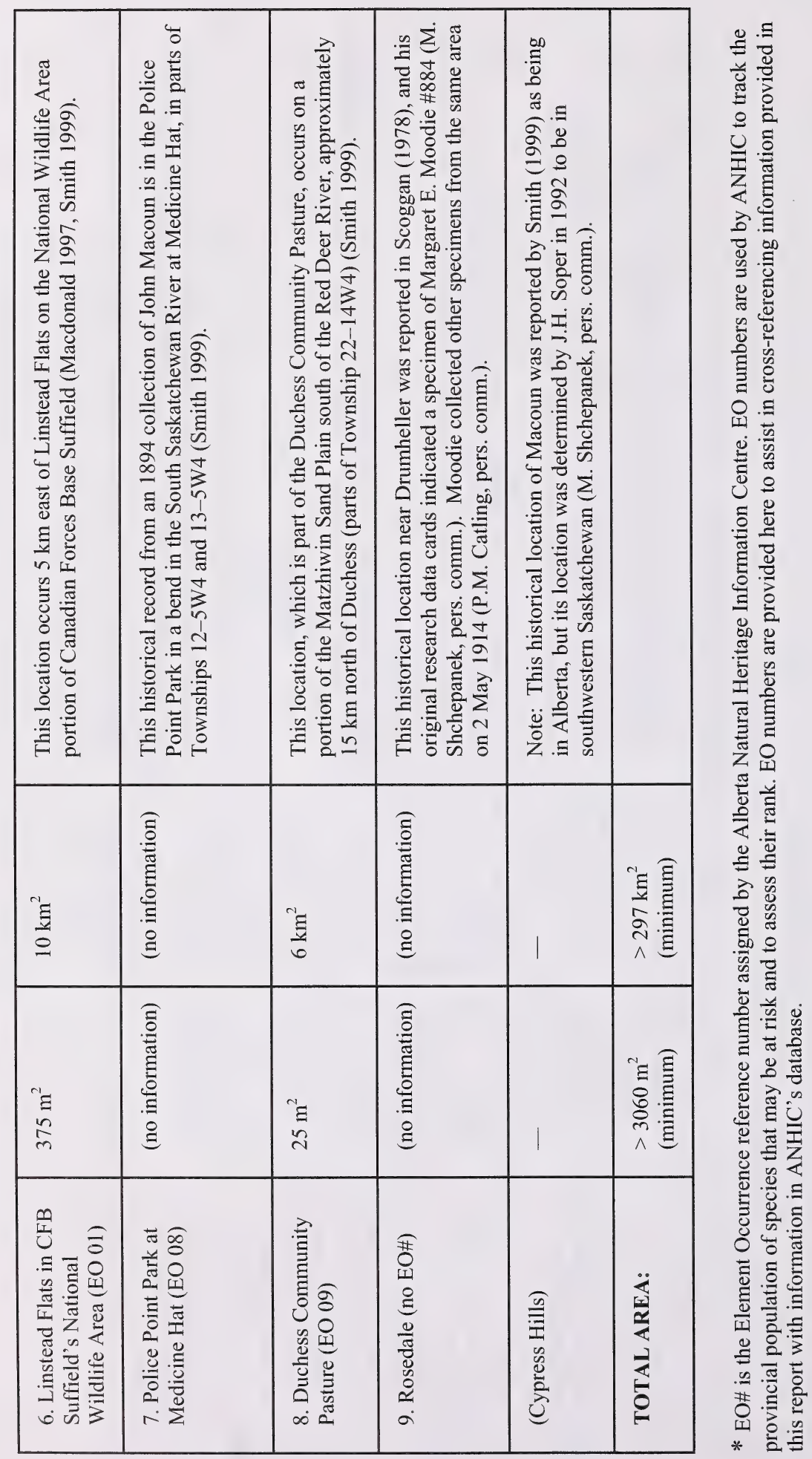


pers. comm.; P.M. Catling, pers. comm.; M. Waterway, pers. comm.; C. Niezgoda, pers. comm.). Although it does appear that H.J. Scoggan made note of its existence (M. Shchepanek, pers. comm.), formal acceptance of this record may have to await its future discovery and confirmation. The third collection record from Alberta was by John H. Hudson in 1978 on the South Saskatchewan River at the Highway 41 bridge (Smith 1991, 1999; location 2 ), and the fifth collection record was by Ian D. Macdonald in 1995, from Linstead Flats in the eastern portion of Canadian Forces Base Suffield National Wildlife Area (Macdonald 1997, Smith 1999; location 6).

A vegetation survey conducted in 1997 by Bonnie M. Smith between the Alberta/ Saskatchewan border north of McNeill and westward to beyond Duchess, in conjunction with a pipeline development project, uncovered an additional six general locations for the species (Smith 1999; B.M. Smith, pers. comm., Golder Associates 1997): four subsites north of McNeill (location 1a), one along the western slope of the South Saskatchewan River $10 \mathrm{~km}$ west of McNeill (location 3), five along an 8-km long strip outside the northeastern corner of the Canadian Forces Base (CFB) Suffield's northern boundary (location 4), two further to the west along the central portion of this same boundary (location 5), and two along a 4-km strip in the Duchess Community Pasture, $13 \mathrm{~km}$ north of Duchess, west of Dinosaur Provincial Park (location 8). There are likely large numbers of undiscovered populations that could be found over a larger area over a longer period of time with the appropriate effort under good conditions, but this would require extensive fieldwork.

A survey along portions of the area north of CFB Suffield in 1996 did not discover any additional plants (Williams 1996), and a detailed resurvey of all of Smith's general locations in 2002 and of portions of the McNeill and Duchess general locations in 2003 did not discover any living plants or plant remnants, probably because of the ongoing drought conditions. However, a survey in 2004 of the locations north of McNeill (Location 1a), the western slope of the South Saskatchewan River (Location 3), and along portions of the area north of CFB Suffield (Location 4) did rediscover populations (Macdonald 2004, C. Elchuk, pers. comm., Table 2).

Smith (1999) indicated that the known populations at all of the historical and recent locations occupied approximately $3060 \mathrm{~m}^{2}$ in the accumulative area of approximately $20 \mathrm{~km}^{2}$ that she examined at the time, and that this represented much less than $1 \%$ of their total potential habitat within this portion of the Dry Mixedgrass Natural Subregion (ANHIC 2002a). Given the extent of the known habitat in similar sand plains and river basins in this portion of the province, it is apparent that potential habitat may well cover up to $10000 \mathrm{~km}^{2}$. However, the data for determining the species' true extent of occurrence are lacking. Potential habitats may occur as small to relatively large blocks, but appear to be separated and fragmented across the Dry Mixedgrass Natural Subregion, and ongoing agricultural and industrial disturbances constantly compromise such habitats. It is unknown whether genetic exchange between the plant's known locations is possible; however, it is likely that at least the McNeill and Duchess Community Pasture locations have the potential for cross-pollination within their populations. Other populations may be relatively isolated from each other, but there is insufficient information available to evaluate whether there is exchange between them over a long time span.

Trends in the distribution of slender mouse-earcress cannot be accurately estimated, except to note that, as Smith (1999) observed, the consistent presence of previous years' stems indicates that there is some continuity in the population locations between years. There is little or no accurate tracking information on the occurrence or disappearance of populations. 


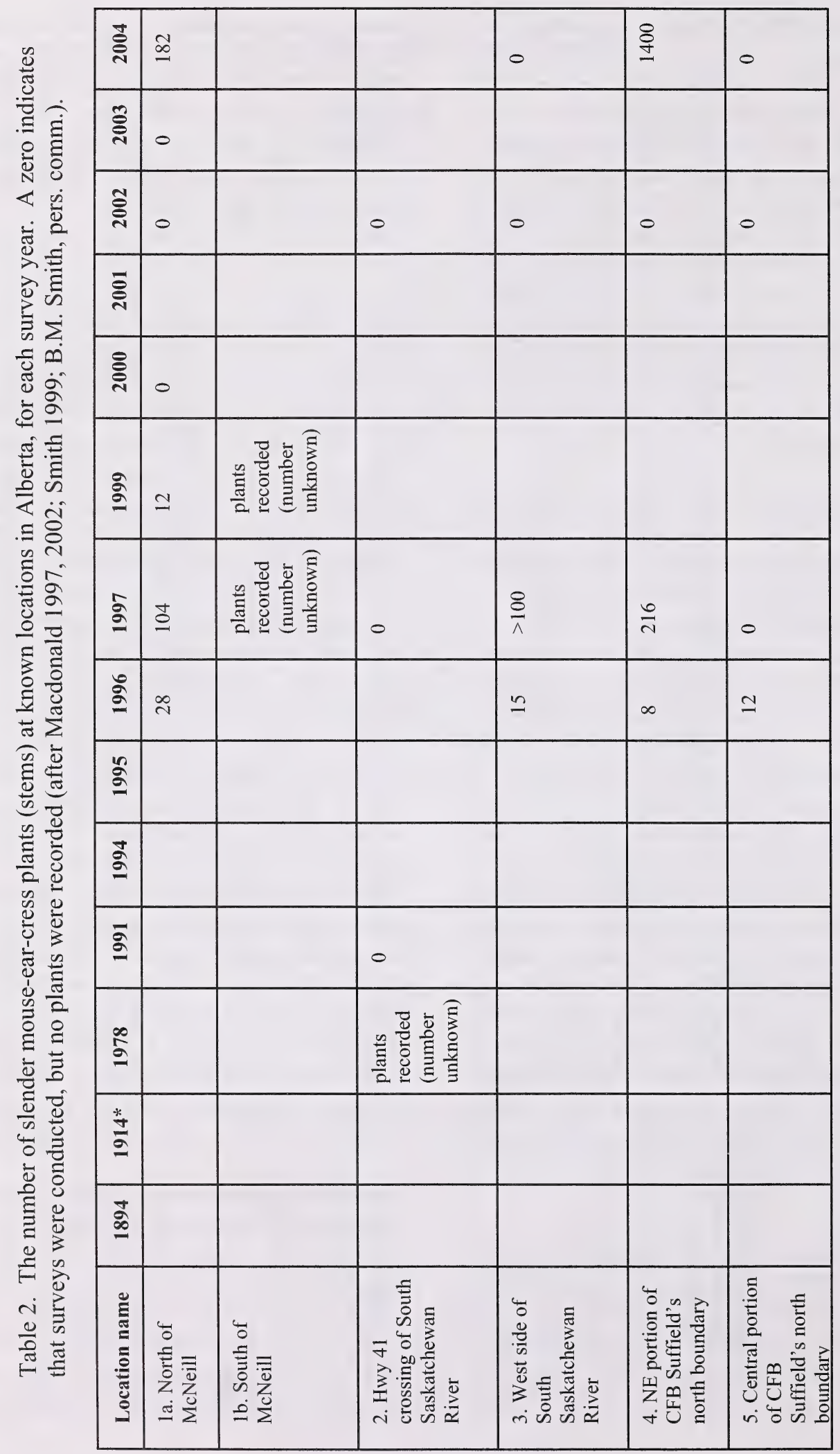




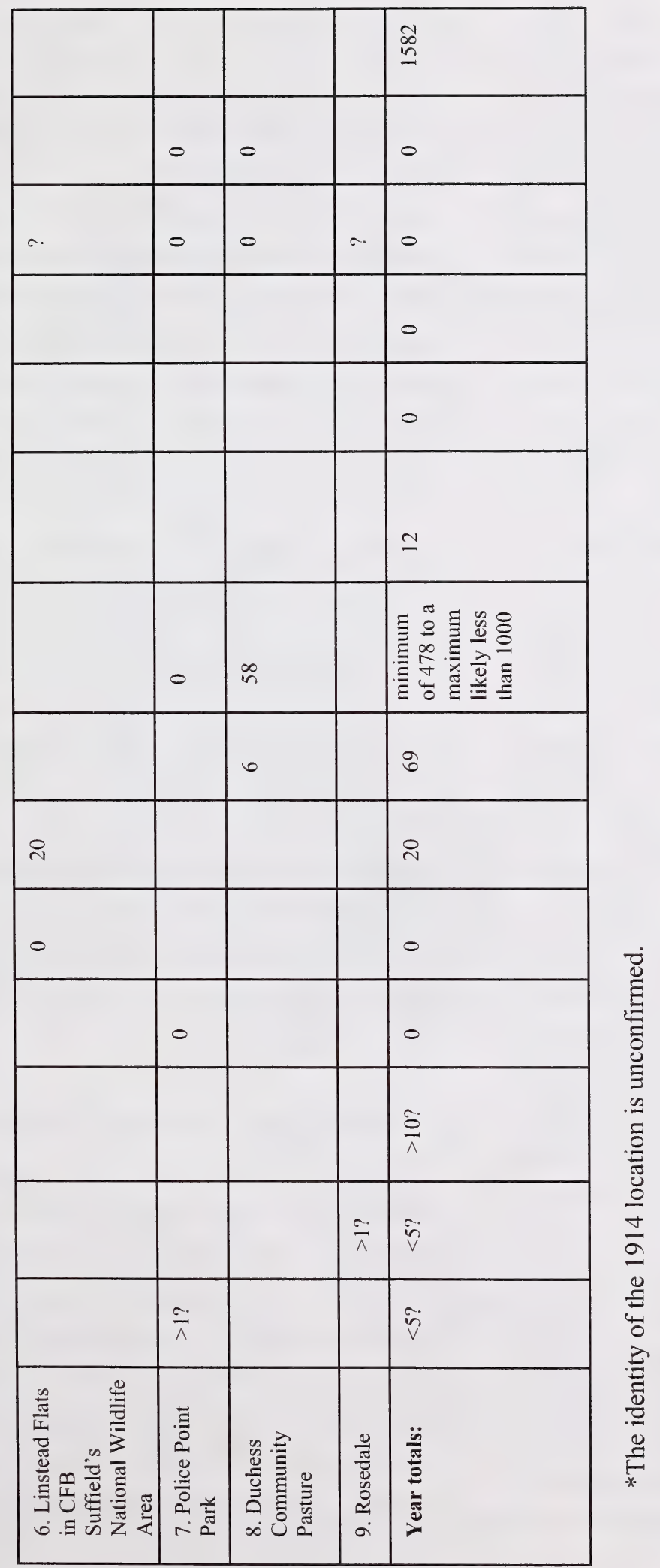


2. Other Areas - Within Canada, Saskatchewan is the only province other than Alberta where slender mouse-ear-cress is known to occur. Prior to 1965 , it had been reported from two locations along the Cypress Hills (including the reported Alberta location that is actually in Saskatchewan) and one from Wood Mountain Post Provincial Historic Park. Since 1965, it has been recorded from at least six locations north of the South Saskatchewan River between the Alberta border and the main body of Lake Diefenbaker, in southwestern Saskatchewan (Figure 2; Smith 1991, 1999; S. Lamont, pers. comm.; J. Keith, pers. comm.; Bedeki-Robson 1997; Elchuk 2002; Breitung 1954).

In the United States, slender mouse-ear-cress occurs in the following states: Montana (all but the extreme northeastern and northwestern corners), Wyoming (all but the eastern edge), Colorado (all but the eastern third and southern margin), Utah (all but the southern margin), Nevada (all but the southeastern and northwestern corners), Idaho (all but the northwestern half) and California (restricted to the east-central interior portion) (Figure 2; Smith 1991, 1999; Scoggan 1978; NatureServe 2004; Hitchcock et al. 1964; Booth and Wright 1959; B. Heidel, pers. comm.; Hartman and Nelson 1998; Montana Natural Heritage Program 2001, 2002; Welsh et. al. 1987; Dorn 1977; California Department of Fish and Game, Natural Diversity Database 2003; Hickman 1993). The inclusion of the westernmost boundaries of North Dakota, South Dakota and Kansas, and the northernmost portion of New Mexico, as indicated in Smith 1991 and 1999, was not substantiated in the map database for the NatureServe Explorer website (NatureServe 2004) or other standard floras (Scoggan 1978). Additionally, the reports of the species from Washington and the Yukon in Hitchcock et al. (1964) and Scoggan (1978) were not substantiated in the NatureServe Explorer website-mapped distributions; these records may have been based on misidentifications of the related northern species, soft mouse-ear-cress (Halimolobos mollis).
No systematic documentation of the persistence of slender mouse-ear-cress populations in the various states or provinces has been conducted. In those states where the species is not abundant, it has not received much attention. In those states where it is considered rare, the management priorities have not afforded any continuous systematic monitoring of the species, or such data are unavailable. Efforts to locate the species in 2002 and 2003 in both Alberta and Saskatchewan were unsuccessful (Macdonald 2002, 2003; Elchuk 2002), and a study of rare plant species ecology in Saskatchewan by Bedeki-Robson (1997) discovered the species in only one location.

It should be noted that, in the adjacent state of Montana, slender mouse-ear-cress has been recorded from the north-facing lower flanks of the Sweetgrass Hills, within less than $10 \mathrm{~km}$ from the Alberta boundary. It also has been recorded from the front and central ranges of the Rocky Mountains, well over $150 \mathrm{~km}$ to the south of the Alberta border. Given the occurrences in Montana and Saskatchewan that are so near the Alberta border and in similar habitats, it is speculated that the species may also occur in Alberta in the vicinities of the north slopes of the Sweetgrass Hills south of the Milk River, the foothills at the extreme southwestern corner of the province, and the Cypress Hills area.

\section{POPULATION SIZE AND TRENDS}

1. Alberta - Information on the number of slender mouse-ear-cress plants in Alberta is very sparse. The two historical records from 1894 and 1914 (unconfirmed) (locations 7,9) included no comment on the number of plants, and that from 1978 (location 2) indicated only "colonies good sized but spottily distributed" (Scoggan 1978; Table 2). No plants have been rediscovered at these locations (Smith 1991, 1999, Macdonald 2002, C. Elchuk, pers. comm.). The record from the Canadian Forces 


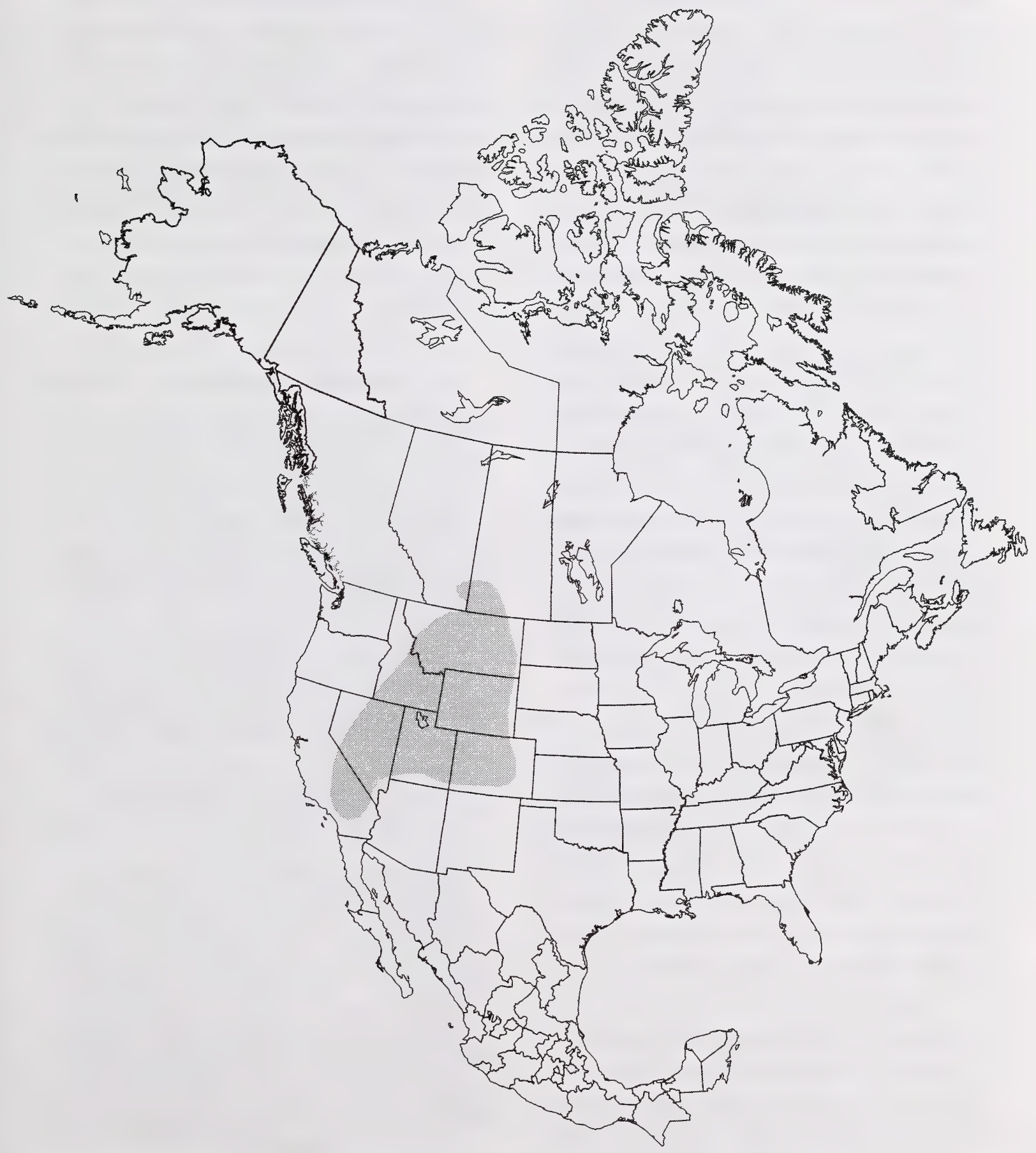

Figure 2. Distribution of slender mouse-ear-cress in North America (after Smith 1999). 
Base Suffield National Wildlife Area in 1995 was the first record to present population data (20 fruiting plants) and area $\left(375 \mathrm{~m}^{2}, 15 \mathrm{~m} \mathrm{x}\right.$ $25 \mathrm{~m}$ ) (Macdonald 1997, Smith 1999) (Table 2), but a search of this location in 2004 did not record any plants (I.D. Macdonald, pers. obs.). Smith's discoveries along a pipeline corridor in the early summer of 1997 identified five general locations with 15 new sites, and she was able to provide partial counts and phenological conditions of plants of the 1997 growing season, as well as a count of the plant stems remaining from the 1996 growing season (Smith 1999; B.M. Smith, pers. comm.; Golder Associates, Ltd. 1997) (Table 2). A subsequent search of the most promising portion of the North McNeill site in 1999 discovered approximately 12 plants (Smith 1999), and a relatively thorough search of the previously reported locations at Medicine Hat and between the McNeill and Duchess areas in 2002 and 2003 did not record any live current year plants or remnants of the previous years' plants (Macdonald 2002, Macdonald unpubl. data.). However, searches for the species in 2004 uncovered 182 plants at the North McNeill location and 1400 plants at the northeast of CFB Suffield (C. Elchuk, pers. comm.) (Table 2).

Several factors limit the accuracy of assessing population size for slender mouse-ear-cress in the province. The earliest collection records of Macoun, Moodie and Hudson either provided no number of plants or provided only general information. The 1995 record of Macdonald provided plant numbers and area, but the area beyond the immediate vicinity of the vegetation survey grid was not searched for additional plants (Macdonald 1997, Adams et al. 1997). The survey conducted by Smith in 1997, which provided plant numbers and general locations, was restricted to a $30-\mathrm{m}$ to $50-\mathrm{m}$ wide corridor with only occasional extensions of up to $200 \mathrm{~m}$, and no accurate locations could be provided (Golder Associates, Ltd. 1997; B.M. Smith, pers. comm.). Her subsequent searches for the species in 1999 and 2000 covered only restricted portions of the locations from 1997 (B.M. Smith, pers. comm.). The search in 2002 was hampered by the extreme drought conditions of the previous two years, and there was no evidence of any slender mouse-ear-cress plants in that or the following year (Macdonald 2002). Indeed, such extremely dry conditions may have greatly reduced the appearance of seedlings and mature plants of the species, either by repressing seed germination, prematurely shrivelling and killing seedlings and maturing plants, or interrupting seed production directly through desiccation or interfering with pollination or other environmental factors.

Population trends for slender mouse-ear-cress in Alberta cannot be determined at this time because of several factors: the species' rarity in the province, the lack of monitoring effort, and the difficulty that surveyors may have had in identifying this technically complex species. Variation in the number of slender mouse-earcress plants observed from year to year is likely a result of both natural variation in numbers and the variability in survey effort for the species. The magnitude of variation in the number of plants is unknown.

2. Other Areas - In Saskatchewan, the size of the slender mouse-ear-cress populations at most of the locations has been indicated only by qualitative terms such as "rare, frequent, abundant" and in a single case "one only" (Hudson, specimen labels, in Smith 1991). In 1997, the species was discovered at two locations in the vicinity of Estuary, Saskatchewan, where eight live plants and 15 old stems from 1996 were found (Smith 1999). In 1999, all known locations were resurveyed, but no plants were recorded at any of the locations (Smith 1999). A separate reconnaissance of rare plant ecology in Saskatchewan in 1996 found some plants at only one of the then-known locations (BedekiRobson 1997), and a resurvey for these populations in 2002 found no plants at any of the locations (Elchuk 2002).

No information was available for the sizes of the populations in the states where the species 
is rare: California, Utah and Colorado (California Natural Diversity Database 2003, Utah Division of Wildlife Resources 1998, Colorado Natural Heritage Program 2003). In Wyoming and Montana, where the species is not rare, it is listed as being sparse to frequent in the locations where it has been documented, and indeed, in range evaluations in Wyoming, it is treated as an "increaser" (a species that increases its cover with grazing pressure) (B. Heidel, pers. comm.). No information is available for the states where slender mouse-ear-cress merely has been reported: Idaho and Nevada (NatureServe 2004).

\section{LIMITING FACTORS}

\section{Habitat Loss, Alteration and Fragmentation}

- One of the most widely recognized requirements for the protection of species is the conservation of potential habitat (Schemske et al. 1994). More than two-thirds of the Dry Mixedgrass Natural Subregion has been destroyed by cultivation in Alberta (Wallis 1987; Samson and Knopf 1994), leaving only a small portion of original native prairie. Smith (1991) noted that increased grazing pressure on the remaining rangeland had changed the plant composition in a variety of habitats.

The known locations for slender mouse-ear-cress in the province occur within relatively large areas of potential habitat, from over $600 \mathrm{~km}^{2}$ in the areas north of and along the eastern side of Canadian Forces Base Suffield, to less than $1 \mathrm{~km}^{2}$ in the river valley locations. In most cases, the habitat is found in low intensity pasture, which apparently can be tolerated by the species. However, in a few cases the species is no longer found because the habitat has been converted to recreational uses, or the site has been stabilized, such as at the Highway 41 crossing and Police Point Park locations along the South Saskatchewan River.

The known habitat of slender mouse-ear-cress is associated with mid-grass prairies on sand plains, but there is potential for the species to occur on other substrates and in mixed grassland communities in Alberta, such as those associated with the slopes of the Cypress Hills, and perhaps the Sweetgrass Hills and southern foothills. In many cases, these habitats have been compromised by agricultural and industrial uses, and corridors between remnants are being reduced or are discontinuous. Noss et al. (1997) have noted that to ensure the perpetuation of a species, habitat requirements must be considered in terms of a large landscape of potentially suitable and connected habitats, rather than as isolated, single, disconnected sites.

2. Drought - The effects of the recent drought conditions in southeastern Alberta have been to greatly reduce the amount of rainfall available throughout the growing season, and to delay the critical early and late stages when germination and initial growth of slender mouse-ear-cress may occur. This undoubtedly is part of a cycle that had origins well before the "dirty thirties", and the effect in the province is that the southern portion of the "Palliser Triangle", with its chronically dry climatic conditions, has shifted northward (H.D.J. McLean, pers. comm.). Although periodic drought appears to be part of the normal cycle for this species, an increase in the severity and duration of drought periods might be detrimental to the species if the longevity of seeds in the seed bank is not sufficient for them to survive the drought. If prolonged drought results in any decrease in the ability of the species to grow and set seed, there may be a further reduction in the number of plants in Alberta, although a return to normal rainfall conditions might allow a rebound in the number of plants.

\section{Reduction/Absence of Grazing Disturbance}

- The species appears to be able to withstand, if not actually require, some level of light disturbance. In Wyoming, range surveys classify it as an "increaser", meaning that it is a species that not only is able to tolerate a modest level of grazing and disturbance, but may even prosper 
under these conditions (B. Heidel, pers. comm.). Three of the areas where slender mouse-ear-cress has been recorded (McNeill, the Canadian Forces Base Suffield area and the Duchess Community Pasture) are currently under a light grazing regime that has been reduced even more as a result of the drought conditions. Detrimental impacts on the populations may be anticipated in situations where there is intense, long-term grazing pressure that exceeds the normal carrying capacity of the rangeland. The Duchess Community Pasture, which normally has 1 cow per 40 acres, had no cattle in 2001 and reduced its usual cattle load by $70 \%$ in 2002 , to only 130 cattle, for a shortened, two-month period (B. Hale, pers. comm.). Similarly, the McNeill location had only $15 \%$ of its normal number of cattle in 2002, mostly because of the sensitivity of the sandy terrain and lack of forage growth (F. Wittig, pers. comm.). The areas along the northern boundary of Canadian Forces Base Suffield also appear to have had greatly reduced grazing pressure since the beginning of the drought in 2000. At this point, it is unlikely that the reduced grazing pressure at these locations has negatively affected the slender mouse-earcress population, but this should be monitored.

\section{Competition from Introduced Species - In} many of the lightly grazed native prairie situations, the introduction of non-native species, either as invasive weeds or as improvement species for grazing and stabilization, is not a serious problem. This is the situation for the slender mouse-ear-cress locations north of McNeill and north of Canadian Forces Base Suffield. The Duchess Community Pasture has not used crested wheat grass for improvement, although there is a notable presence of pasture sagewort (Artemisia frigida) and prickly pear. However, competition from introduced species is a problem at some locations. The Highway 41 crossing of the South Saskatchewan River has a vigorously overwhelming growth of crested wheat grass among the dense silver sagebrush thickets at the probable site reported by Hudson. The historical Police Point Park location (an interpretive park), as indicated above, also has become overgrown with sagebrush and has lawn species and a variety of weeds in the undergrowth. Smith (1999) noted that awnless brome grass (Bromus inermis) and sweet yellow clover (Melilotus officinalis) were a problem in Saskatchewan, and Macdonald (2002) noted that tumbling mustard (Sisymbrium altissimum) was locally common along the north side of Canadian Forces Base Suffield.

5. Recreational Use - Recreational use by the general public is not a problem at the known locations for the species in the province, because they are under private ownership or have management regulations that restrict recreation use by all-terrain vehicles. The historical location at Police Point Park in Medicine Hat has a series of interpretive and parking facilities, but the overall river shore and floodplain features noted by Macoun in 1894 still persist. However, subsequent control of seasonal floodwater probably has changed the habitat somewhat.

\section{STATUS DESIGNATIONS}

1. Alberta - Slender mouse-ear-cress has been on several provincial lists for candidate rare species since the late 1970s (Argus and White 1978, Packer and Bradley 1984). In 2000, the species was considered May Be At Risk in Alberta, according to the general status exercise conducted by Alberta Sustainable Resource Development (Alberta Sustainable Resource Development 2000). The species is currently designated by the Alberta Natural Heritage Information Centre (Vujnovic and Gould 2002) and NatureServe (2004) as being G4 N2 S1.

2. Other Areas - In May 2000, the Committee on the Status of Endangered Wildlife in Canada listed slender mouse-ear-cress as Threatened (COSEWIC 2003). This is a recent downgrade from its previous, more critical, status of

* See Appendix 1 for definitions of selected status designations. 
Endangered, assigned in 1992 (COSEWIC 2002). Argus and Pryer (1990) classified the species as being one of 67 species in Alberta that had a Canadian Priority 4 (out of 5) rating. The new federal Species at Risk Act recognizes the species on Schedule 1, in the Threatened category (Government of Canada 2003). The only other province in Canada that includes this species in its flora is Saskatchewan, where it also is regarded as currently having a status of S1, with only six locations supporting populations since 1990, and three additional historical locations at which populations have not been rediscovered (Smith 1991, 1999; Saskatchewan Conservation Data Centre 2001; S. Lamont, pers. comm.).

In the United States, the species has a ranking of N2N3 (NatureServe 2004). The adjacent state of Montana currently places this species' rank as S3 (Montana Natural Heritage Program 2002; B. Heidel, pers. comm.). Similarly, Wyoming currently ranks this species as S3 (Wyoming Natural Diversity Database 2002), and in both states, the species is on the watch list (B. Heidel, pers. comm.). In Utah, the species has a rank of $\mathrm{S} 1$, and is listed with locations in only four counties (Welsh et al. 1987, Utah Division of Wildlife Resources 1998, Utah Conservation Data Center 2003, NatureServe 2004). The Colorado Natural Heritage Program includes it in its list of "Tracked Vascular Plant Species", as having a rarity rank of S1?, indicating that it is undoubtedly rare, although there is some question about its exact rank (Colorado Natural Heritage Program 2003, NatureServe 2004). In California, although it is not listed in the California Natural Diversity Database of endangered and threatened plants, it is included in its list of "special" plants with a rank of S1.3? (California Natural Diversity Database 2003). In Nevada and Idaho the species has only SNR status (NatureServe 2004), and it has not been listed as having significant status in the Nevada Rare Plant Atlas (Nevada Natural Heritage Program 2001).
It is possible that the species has been overlooked in past inventories because of its very infrequent occurrence and its resemblance to more common species, and it is likely that, particularly in its vegetative stage, it has been overlooked in range surveys. Hence, its detailed distribution within the prairies of Canada, and quite possibly those of the United States as well, may well be underestimated.

\section{RECENT MANAGEMENT IN ALBERTA}

No management plans specifically for the conservation and protection of slender mouseear-cress have been initiated in Alberta ( $\mathrm{J}$. Rintoul, pers. comm.). All but two of the known locations for the species are under private ownership, and up to this point no concern has been expressed to the owners about the populations within their control. One of the publicly owned locations is at Police Point Park in Medicine Hat, where the species has not been reported since the late 1800s; however, the park is not a provincially designated protected area (K. Vujnovic, pers. comm.). The one location that is under current protection is the Linstead Flats location in the Canadian Forces Base Suffield National Wildlife Area. This area is protected from general disturbance by its use designation, which precludes most human activities, including the armoured tank training activities of the base operations (G.C. Trottier, pers. comm.). Currently, there are no active petrochemical activities in the vicinity of this population, and the immediate vicinity of this location would be excluded from disturbance. Otherwise, the only potential for disturbance may be from the little-used vehicle trail that passes adjacent to several of the plants. The extreme isolation of the location and the considerable access restrictions within the base further protect the population.

In Saskatchewan and Wyoming, conservation management of the species appears to be limited 
to continued inventories, monitoring, and landowner cooperation and stewardship encouragement activities (S. Lamont, pers. comm.; B. Heidel, pers. comm.).

\section{SYNTHESIS}

The infrequency of records of slender mouseear-cress makes it difficult to determine the species' true significance in Alberta. It is known mostly from several widespread sand plain grassland locations in Alberta's Grassland Natural Region, and also from river valley sites. There is good potential for it also to be found in the slope meadows of the Cypress Hills, Sweetgrass Hills and southern foothills of the province. Currently, it is considered to be May Be At Risk in Alberta (Alberta Sustainable Resource Development 2000), Threatened in Canada (COSEWIC 2003) and is on Schedule 1 of the federal Species at Risk Act (Government of Canada 2003).

Several research pursuits and management activities would be valuable in confirming the status of slender mouse-ear-cress in Alberta. Systematic early-season monitoring of the known locations should be undertaken on a regular basis. Pursuit of additional new populations in the known potential habitat would be productive, especially in other suitable sand plains grasslands and slope grasslands in the
Cypress Hills, Sweetgrass Hills and southern foothills. Research into the ecological requirements of the species, particularly with respect to its success in developing and setting seed, would help to clarify the plant's chances of long-term survival in Alberta. Information regarding which species of insects are active in pollinating slender mouse-ear-cress, and whether the species may also be self-pollinated, would be helpful not only in broadening our understanding of the seed production process, but also perhaps in identifying potential habitat conditions. Additionally, while wind probably plays a major role in spreading the seeds once the siliques dehisce, their germination success is unknown. Research on gene exchange within or between locations for the species is also needed. Given the probable confusion of this species with more common species, range surveyors, researchers, managers and concerned landowners should be advised of the potential for this species' occurrence, and should be assisted in its identification.

Ultimately, the preservation of this species in Alberta will require the cooperation of private landowners, public managers and management advisors, through the use of conservancy agreements, facilitated management options, and a shared understanding and appreciation of the Grassland Natural Region. 


\section{LITERATURE CITED}

\section{Publications and Reports}

Adams, G.D., G.C. Trottier, W.L. Strong, I.D. Macdonald, S.J. Barry, P.G. Gregoire, G.W. Babish and G. Weiss. 1997. Vegetation component report - Canadian Forces Base Suffield National Wildlife Area - wildlife inventory. Canadian Wildlife Survey, Environment Canada, Prairie and Northern Region, Edmonton, AB. $v+96 p p$.

Agriculture and Agri-Food Canada. 2003. Drought Watch - 2002. [web application] URL: http://www.agr.gc.ca/ pfra/droughtprairie2002 and http:// www.agr.gc.ca/pfra/drought/drmaps_e [accessed 18 January 2003]

Alberta Environment. 2003. Alberta Environment Precipitation Map Summaries 2002-2003. URL: http:// www3.gov.ab.ca/env/water/ws/data/ precipmaps/precipmaps [accessed 18 January 2003]

Alberta Environmental Protection. 1996. The status of Alberta wildlife. Alberta Environmental Protection, Natural Resources Service, Wildlife Management Division. Edmonton, AB. $44 \mathrm{pp}$.

Alberta Forestry, Lands and Wildlife. 1991. The status of Alberta wildlife. Alberta Forestry, Lands and Wildlife, Fish and Wildlife Division. Edmonton, AB. 49 pp.

Alberta Natural Heritage Information Centre (ANHIC). 2001. List of Vascular Plant Elements, 19 November 2001. Alberta Natural Heritage Information Centre, Recreation and Protected Areas, Alberta Environmental Protection, Edmonton, AB. URL: http://www.cd.gov.ab.ca/ preserving/parks/anhic/docs/ vascular_plant_list.pdf [accessed 30 October 2003]

Alberta Natural Heritage Information Centre (ANHIC). 2002a. Natural Regions and Subregions of Alberta. Parks and Protected Areas, Alberta Community Development, Edmonton, AB. URL: http://www.cd.gov.ab.ca/preserving/ parks/anhic/natural_regions_map.asp [updated October 2002].

Alberta Natural Heritage Information Centre (ANHIC). 2002b. Rank Definitions. URL: http://www.cd.gov.ab.ca/ preserving/parks/anhic/definitions.asp [updated October 2002].

Alberta Natural Heritage Information Center (ANHIC). 2003. Rare plant data files. Parks and Protected Areas, Alberta Community Development, Edmonton, AB. [accessed March 2003]

Alberta Soil Survey. (no date). Soils of the Medicine Hat Area $72 \mathrm{~L} / \mathrm{NE}, 72 \mathrm{~L} / \mathrm{NW}$. (Map-scale 1:125000)

Alberta Sustainable Resource Development. 2000. Vascular plants: 2000 preliminary general status ranks for Alberta. Unpublished report, Alberta Sustainable Resource Development, Fish and Wildlife Division, Edmonton, AB.

Alberta Sustainable Resource Development. 2001. The general status of Alberta wild species 2000. Alberta Sustainable Resource Development, Fish and Wildlife Service, Edmonton, AB. 46 pp.

Argus, G.W., and K.M. Pryer. 1990. Rare vascular plants in Canada: our natural heritage. Botany Division, Canadian Museum of Nature, Ottawa, ON. 191 pp. + maps. 
Argus, G.W., and D.J. White. 1978. The rare vascular plants of Alberta. National Museum of Natural Sciences, National Museums of Canada, Ottawa, ON.

Bedeki-Robson, D. 1997. Ecology of rare vascular plants in southwestern Saskatchewan. M.Sc. Thesis, University of Saskatchewan, Saskatoon, SK.

Booth, W.E., and J.C. Wright. 1959. Flora of Montana. Montana State University, Bozman, MT.

Breitung, A.J. 1954. A botanical survey of the Cypress Hills. Canadian Field-Naturalist 68:55-92.

California Department of Fish and Game, Natural Diversity Database. 2003. Special Vascular Plants, Bryophytes, and Lichens List, January 2003. Biannual Publication, Mimeo, 141 pp. URL: http:/ /www.dfg.ca.gov/whdab/pdfs/ SSPlants.pdf [accessed 21 January 2003]

California Natural Diversity Database. 2003. State and Federally Listed Endangered, Threatened, and Rare Plants on California. California Department of Fish and Game, Habitat Conservation Division, Wildlife and Habitat Data Analysis Branch, California Natural Diversity Database. URL: http:// www.dfg.ca.gov/whdab/pdfs/ TEPlants.pdf [accessed 21 January 2003].

Colorado Natural Heritage Program. 2003. Tracked vascular plant species. Colorado State University. URL: http:// www.cnhp.colostate.edu/tracking/ vascular.html [accessed 21 January 2003]
Committee on the Status of Endangered Wildlife in Canada - COSEWIC. 2002. Database. Committee on the Status of Endangered Wildlife in Canada. Ottawa, ON. [version 21 January 2002] URL: http://www.cosewic.gc.ca [accessed 21 January 2003]

Committee on the Status of Endangered Wildlife in Canada - COSEWIC. 2003. Canadian Species at Risk, May 2003. Committee on the Status of Endangered Wildlife in Canada, Ottawa ON. iii + $43 \mathrm{pp}$.

Dorn, R.D. 1977. Manual of the vascular plants of Wyoming: Volume 1. Equisetaceae to Grossulariaceae. Garland Publishing Inc., New York and London. 801 pp.

Douglas, G.W., G.B. Straley and D.V. Medinger. 1998a. Rare vascular plants of British Columbia. B.C. Ministry of Environment, Lands and Parks, B.C. Ministry of Forests Research Branch, and Royal B.C. Museum, Victoria, BC.

Douglas, G.W., G.B. Straley, D. Medinger and J. Pojar. 1998b. Illustrated flora of British Columbia - Volume 2: Dicotyledons (Balsaminaceae through Cuscutaceae). British Columbia Ministry of Environment, Lands and Parks and Ministry of Forestry, Victoria, BC. 401 pp.

Ealey, D.M., editor. 1993. Alberta plants and fungi - master species list and species group checklists. Alberta Forestry, Lands and Wildlife, Edmonton, AB. v +165 pp.

Elchuk, C. 2002. Rare vascular plants: 2002 report - Habitat Stewardship of Rare Species in Saskatchewan. Report to Nature Saskatchewan, Saskatoon, SK. 
Golder Associates, Ltd. 1997. (unnamed proposed pipeline route report: McNeill to Pincer Creek, surveyed by B.M. Smith - June 1997). Unpublished report, Golder Associates, Ltd., Calgary, AB.

Government of Canada. 2003. Species At Risk Act public registry. URL: http:// www.sararegistry.gc.ca/default_e.cfm [Last updated: December 4, 2003]

Hartman, R. and B.E. Nelson. 1998. Atlas of the Flora of Wyoming. Rocky Mountain Herbarium, University of Wyoming, Laramie WY. URL: http:// www.esb.utexas.edu/tchumley/wyomap/ BRA/halvir.pdf [accessed 22 January 2003]

Hickman, J.C. 1993. The Jepson manual higher plants of California. University of California Press, Berkely CA. xvii + $1400 \mathrm{pp}$.

Hitchcock, C.L., A. Cronquist, M. Owensby and J.W. Thompson. 1964. Vascular plants of the Pacific Northwest - Part 2: Salicaceae to Saxifragaceae. University of Washington Press, Seattle, WA. 597 pp.

Kartesz, J.T. 1994a. A synonymized checklist of the vascular flora of the United States, Canada, and Greenland (second edition): Volume 1 - Checklist. Timber Press, Portland, OR. lxi +622 pp.

Kartesz, J.T. 1994b. A synonymized checklist of the vascular flora of the United States, Canada, and Greenland (second edition): Volume 2 - Thesaurus. Timber Press, Portland, OR. vii +816 pp.

Kershaw, L., J. Gould, D. Johnson and J. Lancaster. 2001. Rare vascular plants of Alberta. Alberta Native Plant Council, University of Alberta Press, Edmonton, AB. xliv $+484 \mathrm{pp}$.
Macdonald, I.D. 1997. Vascular plant flora component report - Canadian Forces Base Suffield National Wildlife Area wildlife inventory. Canadian Wildlife Service, Environment Canada, Prairie and Northern Region, Edmonton, AB. vi $+209 \mathrm{pp}$.

Macdonald, I.D. 2002. Status of the slender mouse-ear cress (Halimolobos virgata) in Alberta: report on the on-site survey phase - June 2002. Unpublished report prepared for Species at Risk Division, Canadian Wildlife Service, Saskatoon, SK. 21 pp.

Macdonald, I.D. 2003. Six prairie National Wildlife Areas in southern Saskatchewan - rare vascular plants and Species at Risk Act species. Canadian Wildlife Service, Environment Canada, Saskatoon SK. iv $+50 \mathrm{pp}$.

Macdonald, I.D. 2004. Species at Risk Survey - 2004 - Alberta: Halimolobos virgata (slender mouse-ear-cress). Unpublished report for Canadian Wildlife Service, Northern and Prairie Region, Saskatoon SK. $9 \mathrm{pp}$.

Montana Natural Heritage Program. 2001. Species of Special Concern: Watch Lists. Natural Heritage Network. URL: http:/ /nris.state.mt.us/mtnhp [accessed 21 January 2003]

Montana Natural Heritage Program. 2002. Species of Concern. Montana Natural Resource Information System. URL: mtnhp@state.mt.us [accessed 28 January 2003]

Moss, E.H. 1983. Flora of Alberta - second edition (revised by John G. Packer). University of Toronto Press, Toronto ON. xiii +687 pp. 
National Research Council. 1995. Science and the Endangered Species Act. National Academy Press, Washington, DC. 271 pp.

NatureServe. 2004. NatureServe Explorer: an online encyclopedia of life [web application]. Version 3.0. Arlington, Virginia, USA: NatureServe. URL: http://www.natureserve.org/explorer [updated 1 July 2004].

Nevada Natural Heritage Program. 2001. Nevada Rare Plant Atlas. Nevada Department of Conservation and Natural Resources, Carson City NV. [version 8 August 2001] URL: http:// heritage.nv.gov/atlas/atlas.html [accessed 22 January 2003]

New York Botanical Garden. 2002. Vascular plant catalogues of the intermountain region of U. S. - June 18, 2002. New York Botanical Garden, Bronx, NY. URL: http://nybg.org/bsci/hcol/intf/ Brassicaceae [accessed 22 January 2003]

Noss, R.F., M.A. O'Connell and D.D. Murphy. 1997. The science of conservation planning: habitat conservation under the Endangered Species Act. Island Press, Washington CDC. 246 pp.

Packer, J.G., and C.E. Bradley. 1984. A checklist of the rare vascular plants of Alberta. Natural History Occasional Paper No. 5, Provincial Museum of Alberta and Alberta Culture, Historical Resources Division, Edmonton, AB. 112 pages

Samson, F., and F. Knopf. 1994. Prairie conservation in North America. Bioscience 44:418-421.

Saskatchewan Conservation Data Centre. 2001. Rare vascular plants of Saskatchewan tracking list. Saskatchewan
Conservation Data Centre, Fish and Wildlife Branch, Saskatchewan Environment, Regina, SK. 35 pp.

Saskatchewan Conservation Data Centre. 2003. Ecoregions of Saskatchewan [web application]. Saskatchewan Environment and Saskatchewan Conservation Data Centre, Regina, SK. URL: http://www.biodiversity.sk.ca/ eco.htm [accessed 18 January 2003]

Schemske, D.W., B.C. Husband, M.H. Ruckelhaus, C. Goodwillie, I.M. Parker and J.G. Bishop. 1994. Evaluating approaches to the conservation of rare and endangered plants. Ecology 75: 584-606.

Scoggan, H.J. 1978. The flora of Canada: Part 3 - Dicotyledoneae (Saururaceae to Violaceae). Publications in Botany, No 7(3), National Museum of Natural Sciences, Ottawa ON. pp. 547-1115.

Smith, B.M. 1991. Status report on endangered wildlife in Canada-slender mouse-ear cress (Halimolobos virgata (Nutt.) O.E. Schulz) (draft). Committee on the Status of Endangered Wildlife in Canada, Ottawa, ON. iii +27 pp.

Smith, B.M. 1999. Update: COSEWIC status report on slender mouse-ear cress (Halimolobos virgata) (draft). Committee on the Status of Endangered Wildlife in Canada, Ottawa, ON. v +15 pp.

Usher, R.G., and W.L. Strong. 1994. Ecological classification for the proposed Suffield National Wildlife Area. Prepared for Environment Canada, Conservation and Protection, by GAIA Consultants Inc., Edmonton, and Ecological Land Surveys, Ltd., Edmonton, AB. 37 p +2 appendices +12 maps (1:50,000 scale) 
Utah Conservation Data Center. 2003. Atlas of vascular plants. Department of Geology, University of Utah [web application]. URL: http://www.gis.usu.edu/ Geography-Department/utgeo/utatlas [accessed 21 January 2003]

Utah Division of Wildlife Resources. 1998. Inventory of sensitive species and ecosystems in Utah. Endemic and rare plants of Utah: an overview of their distribution and status. Utah Reclamation Mitigation and Conservation Commission and U.S. Department of the Interior. URL: http:/ /www.utahcdc.usu.edu/ucdc/ ViewReports/plantrpt.pdf [accessed 21 January 2003]

Vujnovic, K., and J. Gould. 2002. Alberta Natural Heritage Information Centre Tracking and Watch Lists - Vascular Plants, Mosses, Liverworts and Hornworts - June 2002. Alberta Natural Heritage Information Centre, Parks and Protected Areas Division, Alberta Community Development, Edmonton, AB. URL: http://www.cd.gov.ab.ca/ preserving/parks/anhic/index.asp [version: 12 June 2002]

Wallis, C.A. 1987. Critical, threatened and endangered habitats in Alberta. Pages 49-63 in Holroyd, G.L., W.B. McGillivray, P.H.R. Stepney, D.M. Ealey, G.C. Trottier and K.E. Eberhart, editors. Proceedings of the workshop on endangered species in the prairie provinces. Provincial Museum of Alberta Natural History Occasional Paper No. 9, Edmonton, AB. 367 pp.
Welsh, S.L., N.D. Atwood, S. Goodrich and L.C. Higgins, editors. 1987. A Utah flora. Great Basin Naturalist Memoirs, No. 9, Brigham Young University, Provo, UT. 894 pp.

Williams, J.A. 1996. Rare plant survey of high potential sites and mainline segments of the proposed Palliser pipeline - 1996. Unpublished report prepared in association with Ian D. Macdonald and Tera Environmental Consultants, Ltd., Calgary, AB. iii +22 pp.

Wyoming Natural Diversity Database. 2002. Species of Special Concern. URL: http:/ /uwadminweb.uwyo.edu/wyndd/ [version: 25 July 2002]

\section{Maps}

Bindloss 72 L/16. Surveys and Mapping Branch, Canada Department of Energy, Mines and Resources. 1989. (scale 1:50000).

Buffalo 72 L/15. Surveys and Mapping Branch, Canada Department of Energy, Mines and Resources. 1975. (scale 1:50000)

Medicine Hat 72 L. Alberta Environmental Protection (scale 1:250000)

The Middle Sand Hills 72 L/9. Surveys and Mapping Branch, Canada Department of Energy, Mines and Resources. 1976. (scale 1:50000)

Wardlow 72 L/13. Surveys and Mapping Branch, Canada Department of Energy, Mines and Resources. 1991. (scale 1:50000) 
Appendix 1. Definitions of selected legal and protective designations.

A. The General Status of Alberta Wild Species 2000 (after Alberta Sustainable Resource Development 2001)

\begin{tabular}{|c|c|c|}
\hline 2000 Rank & 1996 Rank & Definitions \\
\hline At Risk & Red & $\begin{array}{l}\text { Any species known to be At Risk after formal detailed status } \\
\text { assessment and designation as Endangered or Threatened in } \\
\text { Alberta. }\end{array}$ \\
\hline May Be At Risk & Blue & $\begin{array}{l}\text { Any species that may be at risk of extinction or extirpation, and is } \\
\text { therefore a candidate for detailed risk assessment. }\end{array}$ \\
\hline Sensitive & Yellow & $\begin{array}{l}\text { Any species that is not at risk of extinction or extirpation but may } \\
\text { require special attention or protection to prevent it from becoming } \\
\text { at risk. }\end{array}$ \\
\hline Secure & Green & Any species that is not At Risk, May Be At Risk or Sensitive. \\
\hline Undetermined & $\begin{array}{l}\text { Status } \\
\text { Undetermined }\end{array}$ & $\begin{array}{l}\text { Any species for which insufficient information, knowledge or data } \\
\text { is available to reliably evaluate its general status. }\end{array}$ \\
\hline Not Assessed & $\mathrm{n} / \mathrm{a}$ & $\begin{array}{l}\text { Any species known or believed to be present but which has not yet } \\
\text { been evaluated. }\end{array}$ \\
\hline Exotic/Alien & $\mathrm{n} / \mathrm{a}$ & $\begin{array}{l}\text { Any species that has been introduced as a result of human } \\
\text { activities. }\end{array}$ \\
\hline Extirpated/Extinct & $\mathrm{n} / \mathrm{a}$ & $\begin{array}{l}\text { Any species no longer thought to be present in Alberta } \\
\text { (Extirpated) or no longer believed to be present anywhere in the } \\
\text { world (Extinct). }\end{array}$ \\
\hline Accidental/Vagrant & $\mathrm{n} / \mathrm{a}$ & $\begin{array}{l}\text { Any species occurring infrequently and unpredictably in Alberta, } \\
\text { i.e., outside its usual range. }\end{array}$ \\
\hline
\end{tabular}

\section{B. Alberta Wildlife Act/Regulation}

Species designated as Endangered under Alberta's Wildlife Act include those listed as Endangered or Threatened in the Wildlife Regulation.

\begin{tabular}{|l|l|}
\hline Endangered & A species facing imminent extirpation or extinction. \\
\hline Threatened & A species that is likely to become endangered if limiting factors are not reversed. \\
\hline
\end{tabular}

\section{Committee on the Status of Endangered Wildlife in Canada (after COSEWIC 2002)}

\begin{tabular}{|l|l|}
\hline Extinct & A species that no longer exists. \\
\hline Extirpated & A species that no longer exists in the wild in Canada, but occurs elsewhere. \\
\hline Endangered & A species facing imminent extirpation or extinction. \\
\hline Threatened & A species that is likely to become endangered if limiting factors are not reversed. \\
\hline Special Concern & $\begin{array}{l}\text { A species of special concern because of characteristics that make it particularly } \\
\text { sensitive to human activities or natural events. }\end{array}$ \\
\hline Not at Risk & A species that has been evaluated and found to be not at risk. \\
\hline Data Deficient & $\begin{array}{l}\text { A species for which there is insufficient scientific information to support status } \\
\text { designation. }\end{array}$ \\
\hline
\end{tabular}


Appendix 1 continued.

D. Heritage Status Ranks: Global (G), National (N), Sub-National (S) (after Alberta Natural Heritage Information Centre 2002b, NatureServe 2004)

\begin{tabular}{|l|l|}
\hline G1/N1/S1 & $\begin{array}{l}5 \text { or fewer occurrences or only a few remaining individuals. May be especially } \\
\text { vulnerable to extirpation because of some factor of its biology. }\end{array}$ \\
\hline G2/N2/S2 & $\begin{array}{l}6 \text { to } 20 \text { or fewer occurrences or with many individuals in fewer locations. May be } \\
\text { especially vulnerable to extirpation because of some factor of its biology. }\end{array}$ \\
\hline G3/N3/S3 & $\begin{array}{l}\text { 21 to } 100 \text { occurrences, may be rare and local throughout its range, or in a restricted } \\
\text { range (may be abundant in some locations). May be susceptible to extirpation } \\
\text { because of large-scale disturbances. }\end{array}$ \\
\hline G4/N4/S4 & Typically > 100 occurrences. Apparently secure. \\
\hline G5/N5/S5 & Typically > 100 occurrences. Demonstrably secure. \\
\hline GX/NX/SX & Believed to be extinct or extirpated, historical records only. \\
\hline GH/NH/SH & Historically known, may be relocated in the future. \\
\hline GNR/NNR/SNR & Unranked-conservation status not yet assessed. \\
\hline
\end{tabular}

E. United States Endangered Species Act (after National Research Council 1995)

\begin{tabular}{|l|l|}
\hline Endangered & $\begin{array}{l}\text { Any species which is in danger of extinction throughout all or a significant portion of } \\
\text { its range. }\end{array}$ \\
\hline Threatened & $\begin{array}{l}\text { Any species which is likely to become an endangered species within the foreseeable } \\
\text { future throughout all or a significant portion of its range. }\end{array}$ \\
\hline
\end{tabular}


Appendix 2. Plant species found growing in association with slender mouse-ear-cress habitat in 1995, 2002 and 2003, including those listed in the Habitat section of the report (after Macdonald 1997, 2002; Smith 1999).

variegated horsetail (Equisetum variegatum)

prairie selaginella (Selaginella densa)

crested wheat grass (Agropyron pectiniforme)

western wheat grass (Agropyron [= Pascopyrum] smithii)

slender wheat grass (Agropyron [= Elymus] trachycaulum)

blue grama (Bouteloua gracilis)

sand grass (Calamovilfa longifolia)

Rocky Mountain fescue (Festuca saximontana)

June grass (Koeleria macrantha)

Sandberg bluegrass (Poa sandbergii)

needle-and-thread (Stipa comata)

western porcupine grass (Stipa curtiseta)

silvery-flowered sedge (Carex aenea)

thread-leaved sedge (Carex filifolia)

blunt sedge (Carex obtusata)

sun-loving sedge (Carex pensylvanica var. digyna)

low sedge (Carex stenophylla)

prairie onion (Allium textile)

star-flowered false Solomon's-seal (Smilacina stellata)

goosefoot (Chenopodium pratericola)

mouse-ear chickweed (Cerastium arvense)

bee plant (Cleome serrulata)

purple rock cress (Arabis divaricarpa)

reflexed rock cress (Arabis holboelii var. retrofracta)

annual whitlow-grass (Draba nemorosa)

green tansy mustard (Descurania pinnata)

whitlow-grass (Draba reptans)

prairie rocket (Erysimum asperum)

small-flowered rocket (Erysimum inconspicuum)

common pepper-grass (Lepidium densiflorum)

tumbling mustard (Sisymbrium altissimum)

common wild rose (Rosa woodsii)

annual lupine (Lupinus pusillus)

scurf pea (Psoralea lanceolata)

golden bean (Thermopsis rhombifolia)

yellow prairie violet (Viola nuttallii)

cushion cactus (Coryphantha vivipara)

prickly pear (Opuntia polyacantha)

silverberry (Elaeagnus commutata)

white evening-primrose (Oenothera nuttallii)

scarlet mallow (Sphaeralcea coccinea)

northern fairy candelabra (Androsace occidentalis) 
Appendix 2 continued.

moss phlox (Phlox hoodii)

Fendler's cryptanthe (Cryptantha fendlerii)

western bluebur (Lappula occidentalis)

buckbrush (Symphoricarpos occidentalis)

silver sagebrush (Artemisia cana)

pasture sagewort (Artemisia frigida)

prairie sagewort (Artemisia ludoviciana)

Flodman's thistle (Cirsium flodmanii)

tufted fleabane (Erigeron caespitosus)

gumweed (Grindelia squarrosa)

golden aster (Heterotheca villosa)

skeletonweed (Lygodesmia juncea)

low goldenrod (Solidago missouriensis)

common goat's-beard (Tragopogon dubius) 


\section{List of Titles in This Series}

(as of January 2005)

No. 1 Status of the Piping Plover (Charadrius melodus) in Alberta, by David R. C. Prescott. 19 pp. (1997)

No. 2 Status of the Wolverine (Gulo gulo) in Alberta, by Stephen Petersen. 17 pp. (1997)

No. 3 Status of the Northern Long-eared Bat (Myotis septentrionalis) in Alberta, by M. Carolina Caceres and M. J. Pybus. 19 pp. (1997)

No. 4 Status of the Ord's Kangaroo Rat (Dipodomys ordii) in Alberta, by David L. Gummer. 16 pp. (1997)

No. 5 Status of the Eastern Short-horned Lizard (Phrynosoma douglassii brevirostre) in Alberta, by Janice D. James, Anthony P. Russell and G. Lawrence Powell. 20 pp. (1997)

No. 5 Update 2004. Status of the Short-horned Lizard (Phrynosoma hernandesi) in Alberta. Alberta Sustainable Resource Development. 27 pp. (2004)

No. 6 Status of the Prairie Rattlesnake (Crotalus viridis viridis) in Alberta, by Sheri M. Watson and Anthony P. Russell. 26 pp. (1997)

No. 7 Status of the Swift Fox (Vulpes velox) in Alberta, by Susan E. Cotterill. 17 pp. (1997)

No. 8 Status of the Peregrine Falcon (Falco peregrinus anatum) in Alberta, by Petra Rowell and David P. Stepnisky. 23 pp. (1997)

No. 9 Status of the Northern Leopard Frog (Rana pipiens) in Alberta, by Greg Wagner. 46 pp. (1997)

No. 9 Update 2003. Status of the Northern Leopard Frog (Rana pipiens) in Alberta. Alberta Sustainable Resource Development. 61 pp. (2003)

No. 10 Status of the Sprague's Pipit (Anthus spragueii) in Alberta, by David R. C. Prescott. 14 pp. (1997)

No. 11 Status of the Burrowing Owl (Speotyto cunicularia hypugaea) in Alberta, by Troy I. Wellicome. 21 pp. (1997)

No. 12 Status of the Canadian Toad (Bufo hemiophrys) in Alberta, by Ian M. Hamilton, Joann L. Skilnick, Howard Troughton, Anthony P. Russell, and G. Lawrence Powell. 30 pp. (1998)

No. 13 Status of the Sage Grouse (Centrocercus urophasianus urophasianus) in Alberta, by Cameron L. Aldridge. 23 pp. (1998)

No. 14 Status of the Great Plains Toad (Bufo cognatus) in Alberta, by Janice D. James. 26 pp. (1998)

No. 15 Status of the Plains Hognose Snake (Heterodon nasicus nasicus) in Alberta, by Jonathan Wright and Andrew Didiuk. 26 pp. (1998)

No. 16 Status of the Long-billed Curlew (Numenius americanus) in Alberta, by Dorothy P. Hill. 20 pp. (1998)

No. 17 Status of the Columbia Spotted Frog (Rana luteiventris) in Alberta, by Janice D. James. 21 pp. (1998)

No. 18 Status of the Ferruginous Hawk (Buteo regalis) in Alberta, by Josef K. Schmutz. 18 pp. (1999)

No. 19 Status of the Red-tailed Chipmunk (Tamias ruficaudus) in Alberta, by Ron Bennett. 15 pp. (1999)

No. 20 Status of the Northern Pygmy Owl (Glaucidium gnoma californicum) in Alberta, by Kevin C. Hannah. 20 pp. (1999) 
No. 21 Status of the Western Blue Flag (Iris missouriensis) in Alberta, by Joyce Gould. 22 pp. (1999)

No. 22 Status of the Long-toed Salamander (Ambystoma macrodactylum) in Alberta, by Karen L. Graham and G. Lawrence Powell. 19 pp. (1999)

No. 23 Status of the Black-throated Green Warbler (Dendroica virens) in Alberta, by Michael R. Norton. 24 pp. (1999)

No. 24 Status of the Loggerhead Shrike (Lanius ludovicianus) in Alberta, by David R. C. Prescott and Ronald R. Bjorge. 28 pp. (1999)

No. 25 Status of the Plains Spadefoot (Spea bombifrons) in Alberta, by Richard D. Lauzon. 17 pp. (1999)

No. 26 Status of the Trumpeter Swan (Cygnus buccinator) in Alberta, by M. Lynne James. 21 pp. (2000)

No. 27 Status of the Pygmy Whitefish (Prosopium coulteri) in Alberta, by William C. Mackay. 16 pp. (2000)

No. 28 Status of the Short-eared Owl (Asio flammeus) in Alberta, by Kort M. Clayton. 15 pp. (2000)

No. 29 Status of the Willow Flycatcher (Empidonax traillii) in Alberta, by Bryan Kulba and W. Bruce McGillivray. 15 pp. (2001)

No. 30 Status of the Woodland Caribou (Rangifer tarandus caribou) in Alberta, by Elston Dzus. 47 pp. (2001)

No. 31 Status of the Western Spiderwort (Tradescantia occidentalis) in Alberta, by Bonnie Smith. 12 pp. (2001)

No. 32 Status of the Bay-breasted Warbler (Dendroica castanea) in Alberta, by Michael Norton. 21 pp. (2001)

No. 33 Status of the Cape May Warbler (Dendroica tigrina) in Alberta, by Michael Norton. 20 pp. (2001)

No.34 Status of the Whooping Crane (Grus americana) in Alberta, by Jennifer L. White. 21 pp. (2001)

No. 35 Status of Soapweed (Yucca glauca) in Alberta, by Donna Hurlburt. 18 pp. (2001)

No. 36 Status of the Harlequin Duck (Histrionicus histrionicus) in Alberta, by Beth MacCallum. 38 pp. (2001)

No. 37 Status of the Grizzly Bear (Ursus arctos) in Alberta, by John L. Kansas. 43 pp. (2002)

No. 38 Status of the Wood Bison (Bison bison athabascae) in Alberta, by Jonathan A. Mitchell and C. Cormack Gates. 32 pp. (2002)

No. 39 Status of the Bull Trout (Salvelinus confluentus) in Alberta, by John R. Post and Fiona D. Johnston. 40 pp. (2002)

No. 40 Status of the Banff Springs Snail (Physella johnsoni) in Alberta, by Dwayne A.W. Lepitzki. 29 pp. (2002)

No. 41 Status of the Shortjaw Cisco (Coregonus zenithicus) in Alberta, by Mark Steinhilber. 23 pp. (2002)

No. 42 Status of the Prairie Falcon (Falco mexicanus) in Alberta, by Dale Paton. 28 pp. (2002)

No. 43 Status of the American Badger (Taxidea taxus) in Alberta, by Dave Scobie. 17 pp. (2002)

No. 44 Status of the Yucca Moth (Tegeticula yuccasella) in Alberta. Alberta Sustainable Resource Development. 21 pp. (2002) 
No. 45 Status of the White-winged Scoter (Melanitta fusca deglandi) in Alberta. Alberta Sustainable Resource Development. 15 pp. (2002)

No. 46 Status of the Lake Sturgeon (Acipenser fulvescens) in Alberta. Alberta Sustainable Resource Development. 30 pp. (2002)

No. 47 Status of the Western Silvery Minnow (Hybognathus argyritis) in Alberta. Alberta Sustainable Resource Development. 24 pp. (2003)

No. 48 Status of the Small-flowered Sand Verbena (Tripterocalyx micranthus) in Alberta. Alberta Sustainable Resource Development. 24 pp. (2003)

No. 49 Status of the Brown Creeper (Certhia americana) in Alberta. Alberta Sustainable Resource Development. 30 pp. (2003)

No. 50 Status of the Mountain Plover (Charadrius montanus) in Alberta. Alberta Sustainable Resource Development. 25 pp. (2003)

No. 51 Status of the St. Mary Shorthead Sculpin (provisionally Cottus bairdi punctulatus) in Alberta. Alberta Sustainable Resource Development. 24 pp. (2003)

No. 52 Status of the Stonecat (Noturus flavus) in Alberta. Alberta Sustainable Resource Development. 22 pp. (2003)

No. 53 Status of the Sage Thrasher (Oreoscoptes montanus) in Alberta. Alberta Sustainable Resource Development. 23 pp. (2004)

No. 54 Status of the Tiny Cryptanthe (Cryptantha minima) in Alberta. Alberta Sustainable Resource Development. 39 pp. (2004)

No. 55 Status of the Slender Mouse-ear-cress (Halimolobos virgata) in Alberta. Alberta Sustainable Resource Development. 27 pp. (2005)

No. 56 Status of the Barred Owl (Strix varia) in Alberta. Alberta Sustainable Resource Development. 16 pp. (2005) 

NATIONAL LIBRARY OF CANADA
Bibliothèque nationale du Canada

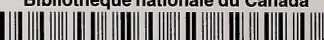

33286530309893 